\title{
Article \\ Enhancing Grain Yield and Nitrogen Accumulation in Wheat Plants Grown under a Mediterranean Arid Environment by Foliar Spray with Papain-Released Whey Peptides
}

\author{
AbdAllah M. El-Sanatawy ${ }^{1}{ }^{(D}$, Salwa M. A. I. Ash-Shormillesy ${ }^{1}$, Ahmed Abou El-Yazied ${ }^{2}$ (D), \\ Hany G. Abd El-Gawad ${ }^{2, *(\mathbb{D})}$, Ehab Azab ${ }^{3} \mathbb{D}$, Adil A. Gobouri ${ }^{4}$, Mahmoud Sitohy ${ }^{5}$ and Ali Osman ${ }^{5, *(D)}$ \\ 1 Agronomy Department, Faculty of Agriculture, Zagazig University, Zagazig 44511, Egypt; \\ elsanatawyabdallah2@gmail.com (A.M.E.-S.); Dr.salwaalymani@gmail.com (S.M.A.I.A.-S.) \\ 2 Department of Horticulture, Faculty of Agriculture, Ain Shams University, Cairo 11566, Egypt; \\ ahmed_abdelhafez2@agr.asu.edu.eg \\ 3 Department of Food Science and Nutrition, College of Science, Taif University, P.O. Box 11099, \\ Taif 21944, Saudi Arabia; e.azab@tu.edu.sa \\ 4 Department of Chemistry, College of Science, Taif University, P.O. Box 11099, Taif 21944, Saudi Arabia; \\ a.gobouri@tu.edu.sa \\ 5 Biochemistry Department, Faculty of Agriculture, Zagazig University, Zagazig 44511, Egypt; \\ mzsitohy@hotmail.com \\ check for \\ updates \\ * Correspondence: hany_gamal2005@agr.asu.edu.eg (H.G.A.E.-G.); Ali_khalil2006@yahoo.com (A.O.); \\ Tel.: +201271262256 (A.O.)
}

Citation: El-Sanatawy, A.M.; AshShormillesy, S.M.A.I.; El-Yazied, A.A.; El-Gawad, H.G.A.; Azab, E.; Gobouri, A.A.; Sitohy, M.; Osman, A. Enhancing Grain Yield and Nitrogen Accumulation in Wheat Plants Grown under a Mediterranean Arid Environment by Foliar Spray with Papain-Released Whey Peptides. Agronomy 2021, 11, 1913. https:// doi.org/10.3390/agronomy11101913

Academic Editors: Mauro Mori and Ida Di Mola

Received: 27 August 2021

Accepted: 21 September 2021

Published: 24 September 2021

Publisher's Note: MDPI stays neutral with regard to jurisdictional claims in published maps and institutional affiliations.

Copyright: (c) 2021 by the authors. Licensee MDPI, Basel, Switzerland. This article is an open access article distributed under the terms and conditions of the Creative Commons Attribution (CC BY) license (https:// creativecommons.org/licenses/by/ $4.0 /)$.
Abstract: Due to their beneficial, stimulating impact on plant growth, productivity, and alleviating environmental stresses, protein hydrolysates have recently received increasing attention as a possible substitute. This investigation aimed to explore the effects of foliar application of papain-produced whey protein hydrolysates (WPH) on the yield attributes and nitrogen use efficiency (NUE) of soft wheat. Wheat plants were cultivated under a Mediterranean arid environment and received four soil nitrogen $(\mathrm{N})$ fertilization levels with ammonium nitrate $\left(145,185,215\right.$, and $\left.250 \mathrm{~kg} \mathrm{~N} \mathrm{ha}^{-1}\right)$ and compared to control treatment and urea foliar application. WPH increased grain yield, yield attributes, and $\mathrm{N}$ accumulation in wheat plants. Partial productivity factors of applied nitrogen, as NUE indicators under relatively steady-state cropping systems, were also enhanced by WPH compared to control treatment. WPH significantly improved flag leaf area, spike number $\mathrm{m}^{-2}$, and grain yield compared to urea foliar application. Increasing the soil $\mathrm{N}$ fertilization level from 145 up to $215 \mathrm{~kg} \mathrm{~N} \mathrm{ha}^{-1}$ was accompanied by significant increases in all yield traits and $\mathrm{N}$ accumulation measurements, except for the partial factor productivity of applied $\mathrm{N}$, which decreased. A strong positive association was detected among grain and straw yields, their attributes, and total $\mathrm{N}$ uptake. Results highlighted the efficacy of WPH in increasing wheat yield and NUE.

Keywords: whey protein hydrolysates; urea foliar application; wheat yield; response curve; principal component analysis; Triticum aestivum L.

\section{Introduction}

Wheat (Triticum aestivum L.) is one of the major economic crops cultivated worldwide alongside with rice (Orayza sativa L.) and maize (Zea mays L.), providing the most food supplies for people, especially in developing countries [1,2]. Wheat supplies more calories and proteins to human consumption than other food crops [3]. Crop production systems are influenced by climatic change and soil fertility [1]. Mineral fertilizers replenish the shortage in soil nutrients for plant requirements, improve crop productivity, and minimize the losses in the quantity and quality of crop yield [4]. Plants require nitrogen (N) to build a photosynthetically active canopy that will vigorously promote yield formation [5]. Moreover, cereal crops require $\mathrm{N}$ to synthesize proteins stored in grains [5]. The increase 
in the global demand for $\mathrm{N}$ is expected to reach 111.59 million tonnes in 2022, with an increased reach of $6.13 \%$ compared to the global demand in 2016 [6].

$\mathrm{N}$ fertilization is one of the agricultural practices that most influence wheat growth, development, and productivity. Many studies revealed that the increase of $\mathrm{N}$ fertilization levels significantly increased wheat yield quantity and quality, especially when soil nitrogen supply was low [2]. Farmers in many countries around the world use high $\mathrm{N}$ input to achieve high yields $[7,8]$. However, the excessive application of nitrogenous fertilizers may reduce grain yield through increasing lodging and disease incidence [9]. Increased $\mathrm{N}$ losses induced by volatilization, denitrification, leaching, or runoff may cause negative environmental effects such as greenhouse gas emission and nitrate leaching [1,5], as well as decreased $\mathrm{N}$ use efficiency (NUE) $[8,10]$. So, optimum $\mathrm{N}$ supply may enable to produce high yield quantity, rationalize the use of $\mathrm{N}$ fertilizer, reduce production costs, and avoid potential environmental threats [1].

Since the NUE of cereal crops is only about 35\% worldwide [8], most applied N (65\%) is not exploited and may be lost. In field investigations, different methods were proposed to estimate nutrient use efficiencies including isotope-labeled fertilizers, mass balance, and difference methods [8]. Difference methods use the differences in crop yield and/or nutrient uptake between fertilized and unfertilized experimental plots in their calculation. Difference method indicators such as agronomic efficiency (AE) and apparent recovery efficiency (RE) are simple and cost-efficient but are not appropriate when comparing cropping systems that are at relatively steady-state with regard to soil nutrient content due to the accumulation of the nutrients from fertilizer in soil organic matter and its impact on the indigenous soil nutrient supply for subsequently grown crops, which make it difficult for accurate evaluation [11]. Under these circumstances, partial factor productivity (PEP), the ratio of grain yield/nutrient amount applied, is a more efficient indicator to evaluate the nutrient use efficiency because of its dependence on applied and soil-stored nutrients in estimating nutrient use efficiency.

Globally, Improving NUE is essential not only for food production but also for the environment [8]. Better $\mathrm{N}$ utilization was noticed when applying $\mathrm{N}$ nutrients to the leaves as foliar spray compared to the soil. Foliar urea application was reported as an efficient method for $\mathrm{N}$ fertilization in cereals crops [12]. Under limited $\mathrm{N}$ supply, urea foliar application may integrate with the $\mathrm{N}$ soil application, fulfilling wheat requirements of $\mathrm{N}$ [13].

Generally, most wheat yield attributes can be improved by foliar urea application, while the application timing determines which yield attribute is more influenced. The preanthesis application may increase spike number $\mathrm{m}^{-2}$ and grain number spike ${ }^{-1}, 1000$-grain weight $[14,15]$, while post-anthesis application can enhance grain yield and bread-making quality [16]. The best urea solution concentration for foliar application was in the range of $1-5 \%[14,15,17]$ based on the varietal differences [18].

Protein hydrolysates are mixtures of free amino acids and polypeptides resulting from chemical and enzymatic hydrolysis of agro-industrial protein by-products derived from plant or animal origins [19]. They are qualified as bio-stimulants capable of promoting plant growth, crop productivity, and alleviating environmental stress impact [20-22]. Protein hydrolysates may enhance nutrient uptake and $\mathrm{N}$ metabolism through the activation of enzymes involved in their metabolism, thus enhancing the use efficiencies of micro and macronutrients [23]. Colla et al. [24] attributed the positive influence of protein hydrolysates on plant growth to the stimulation of $\mathrm{N}$ uptake and assimilation. Protein hydrolysates can be added as foliar spray or soil drench [25]. The beneficial influences of protein hydrolysates were obtained at a low dose $\left(2 \mathrm{~g} \mathrm{~L}^{-1}\right)$ of application on Pisum sativum L. [20].

Whey is a significant by-product from cheese manufacture that contains $6-7 \%$ total solids and represents nearly $20 \%$ total milk proteins [26]. Whey proteins are valuable sources of many protein fractions, e.g., $\alpha$-lactalbumin and $\beta$-lactoglobulin, that have been reported as biologically active in their native or modified forms [27-32]. Proteolytic 
enzymes from microbial and plant sources have been successfully applied to release peptides from whey proteins exhibiting several biological properties [33-39]. Nevertheless, information about the influence of whey protein hydrolysates on plants, particularly wheat, is scarce.

The present investigation hypothesized that whey protein hydrolysates (WPH) produced by papain could enhance wheat productivity and NUE. Hence, this investigation aimed to (i) evaluate the influence of WPH on grain yield, yield attributes, and N accumulation indicators in wheat plants as compared with control treatment and urea; (ii) study the effect of combining WPH or urea with different levels of soil $\mathrm{N}$ fertilization under arid environment on the wheat growth and grain yield; (iii) determine the impact of WPH on NUE using partial factor productivity of applied $\mathrm{N}$ as NUE indicator; and (iv) produce $\mathrm{N}$ fertilizer management regime, enhancing NUE and avoiding yield loss.

\section{Materials and Methods}

\subsection{Whey Protein Hydrolysates Preparation}

The buffalo milk (Zagazig City, Egypt) was centrifuged $(6000 \times g, 10 \mathrm{~min})$ and the resulting skimmed milk was acidified to $\mathrm{pH} 4.6$ to coagulate the caseins [22]. The whey protein hydrolysate (WPH) was obtained as stated by [35] by hydrolysis with papain (E/S ratio $1: 2$ ) for $3 \mathrm{~h}$ with $25 \%$ degree of hydrolysis. HPLC determined free amino acids of the WHP. A $25 \mathrm{~g}, 100 \mathrm{~mL}^{-1}$ aqueous whey protein solution was allowed to hydrate at room temperature for $1 \mathrm{~h}$ with gentle mixing. Before adding the enzyme, the protein solution was equilibrated at $37^{\circ} \mathrm{C}$ and the $\mathrm{pH}$ was modified to 6.0 with $2.0 \mathrm{~N} \mathrm{NaOH}$. The degree of hydrolysis was measured after 1,2, and $3 \mathrm{~h}$ using a previously published method [40]. The hydrolysate was centrifuged at $4000 \times g$ for $30 \mathrm{~min}$ at $4{ }^{\circ} \mathrm{C}$ to remove the insoluble particles, and the supernatant was lyophilized and frozen at $-20^{\circ} \mathrm{C}$ until further use.

\subsection{Antioxidant Activity Estimation}

\subsubsection{DPPH-Assay}

After 1,2 , and $3 \mathrm{~h}$, the antioxidative activity of whey protein hydrolysates $\left(500 \mu \mathrm{g} \mathrm{mL} \mathrm{m}^{-1}\right)$ was assessed according to [41] with minor modifications by calculating the DPPH $(2,2-$ diphenyl-1-picrylhydrazyl) radical scavenging activity. One milliliter of hydrolysate was mixed with $3 \mathrm{~mL}$ of $0.15 \mathrm{mM}$ DPPH (in $95 \%$ ethanol), vigorously shaken with a mixer, and incubated at room temperature for $30 \mathrm{~min}$ before calculating color absorbance at $517 \mathrm{~nm}$. Ethanol was used as a control. The decrease in color absorbance was used to calculate the radical scavenging potential of the samples according to the following equation:

DPPH - radical scavenging activity $(\%)=[($ Abs. control - Abs. sample $)) /$ Abs. control $] \times 100$

\subsubsection{ABTS-Assay}

The antioxidant activity of whey protein hydrolysate was estimated by ABTS $(2,20-$ azino-bis (3-ethylbenzothiazoline 6-sulfonic acid) assay (Merck KGaA, Darmstadt, Germany) and according to Abdel-Hamid et al. [34] and Osman et al. [42]. The ABTS+ solution was prepared with final concentrations of $7 \mathrm{mM}$ ABTS and $2.45 \mathrm{mM}$ potassium persulfate. The mixture was left in the dark at room temperature for $12-16 \mathrm{~h}$ before use. The ABTS+ solution was diluted with $0.2 \mathrm{M}$ in sodium phosphate-buffered saline ( $\mathrm{pH}$ 7.4) before assessing the absorbance of $0.70 \pm 0.02$ at $734 \mathrm{~nm}$. Then $40 \mu \mathrm{L}$ of the sample (containing $500 \mu \mathrm{g} / \mathrm{mL}$ ) was added to $4 \mathrm{~mL}$ of diluted ABTS+ solution. The mixture was shaken vigorously for $30 \mathrm{~s}$ and left in the dark for $6 \mathrm{~min}$. The absorbance of the resultant solution was measured at $734 \mathrm{~nm}$. ABTS-radical scavenging activity was calculated from the following equation:

ABTS - radical scavenging activity $(\%)=[($ Abs. control - Abs. sample $)) /$ Abs. control $] \times 100$ 


\subsection{Electro-Spray-Ionization-Mass-Spectrometry (ESI-MS) of Protein Hydrolysates}

The protein hydrolysate with the highest antioxidant activity was subjected to electrospray-ionization-mass-spectrometry (ESI-MS) positive ion. An aliquot $(10 \mu \mathrm{L})$ of the final hydrolysate solution was injected into the chromatograph and peptides were separated on a XEVO TQD triple quadrupole instrument Waters Corporation, ((34 Maple St, Milford, MA 01757, USA), mass spectrometer. Column: ACQUITY UPLC-BEH C18 $1.7 \mu \mathrm{m}-2.1 \times 50 \mathrm{~mm}$ Column with flow rate: $0.2 \mathrm{~mL} \backslash \mathrm{min}$ using solvent system: consisted of (A) Water containing $0.1 \%$ formic acid; (B) Actonitrile containing $0.1 \%$ formic acid [43].

\subsection{Free Amino Acids Estimation}

One gram of dried material was added to $40 \mathrm{~mL}$ of buffer $(2.5 \mathrm{M}$ citric acid, $0.048 \mathrm{M}$ norleucine, $10 \%$ methanol $(v / v), 0.025$ percent thiodiglycol $(w / v)$, and $0.01 \%$ BRIJ $35(w / v)$ adjusted to $\mathrm{pH}$ of 2.1) and incubated at $4{ }^{\circ} \mathrm{C}$ for $24 \mathrm{~h}$. To precipitate proteins, $2.5 \mathrm{M}$ citric acid, $12 \%$ sulphosalicylic acid $(w / v), 10 \%$ methanol $(v / v), 0.025 \%$ thiodiglycol $(w / v)$, and $0.01 \%$ BRIJ $35(w / v)$ were added to an equal volume of sulphosalicylic acid buffer $(2.5 \mathrm{M}$ citric acid, $12 \%$ sulphosalicylic acid $(w / v)$, and $10 \%$ methanol $(v / v))$. After passing through $0.22 \mathrm{~m}$ Millipore filters (Millipore, Watford, UK), the extracts were promptly tested with the reverse-phase HPLC [20].

\subsection{Field Experiments}

\subsubsection{Site Description}

Two field experiments were carried out at Abu-Hammad District, Sharkia Governorate, Egypt $\left(30^{\circ} 32^{\prime} \mathrm{N}, 31^{\circ} 36^{\prime} \mathrm{E}\right.$ and $74 \mathrm{~m}$ above sea level), during two successive winter seasons: 2017-2018 and 2018-2019. Average monthly climatic conditions at the experimental site during the two growing seasons and the long-term averages of 20-yr are presented in Table 1. Accordingly, the climate in the study region can be classified as arid, with average annual precipitations ranging from $18.9-30 \mathrm{~mm}$ distributed over the months from November to April. Representative soil samples, collected from the experimental sites at the depths of 0-30, 30-60, and 60-90 cm before applying fertilizers, were used to the soil's physical and chemical properties as shown in Table 2. Soil properties data showed that the experimental field soil was sandy clay in texture with low available $\mathrm{N}$ content.

Table 1. Monthly average maximum temperature (Max. T), minimum temperature (Min. T), relative humidity (RH), and total precipitation (P.) in 2017-2018 and 2018-2019 growing seasons as well as 20-yr monthly averages (2001-2019).

\begin{tabular}{|c|c|c|c|c|c|c|c|c|c|c|c|c|}
\hline \multirow{3}{*}{ Month } & \multicolumn{4}{|c|}{ 2017-2018 } & \multicolumn{4}{|c|}{ 2018-2019 } & \multicolumn{4}{|c|}{ 20-yr Average (2001-2019) } \\
\hline & Max. T & Min. T & RH & $\mathbf{P}$ & Max. T & Min. T & RH & $\mathbf{P}$ & Max. T & Max. T & RH & $\mathbf{P}$ \\
\hline & \multicolumn{2}{|c|}{${ }^{\circ} \mathrm{C}-$} & $\%$ & $\mathbf{m m}$ & \multicolumn{2}{|c|}{$\square^{\circ} \mathrm{C}-$} & $\%$ & $\mathbf{m m}$ & \multicolumn{2}{|c|}{${ }^{\circ} \mathrm{C}-$} & $\%$ & $\mathrm{~mm}$ \\
\hline November & 24.20 & 16.23 & 60.98 & 1.02 & 25.46 & 15.70 & 44.57 & 3.00 & 25.10 & 14.32 & 65.00 & 3.00 \\
\hline December & 22.29 & 14.03 & 64.02 & 0.25 & 21.12 & 10.90 & 47.93 & 3.00 & 20.65 & 10.61 & 61.00 & 3.00 \\
\hline January & 19.38 & 11.45 & 60.00 & 5.33 & 19.41 & 7.74 & 59.28 & 6.90 & 18.16 & 8.46 & 63.60 & 7.00 \\
\hline February & 23.75 & 13.67 & 55.31 & 13.46 & 20.39 & 11.50 & 55.55 & 3.01 & 19.64 & 9.60 & 58.70 & 3.00 \\
\hline March & 27.96 & 16.32 & 45.65 & 2.03 & 26.61 & 13.58 & 53.13 & 2.00 & 24.27 & 12.99 & 51.30 & 2.00 \\
\hline April & 29.26 & 18.20 & 44.09 & 6.10 & 28.50 & 12.63 & 48.52 & 1.00 & 28.20 & 15.43 & 46.90 & 1.00 \\
\hline
\end{tabular}


Table 2. Physical and chemical properties of the experimental field soil (averaged over the two growing seasons).

\begin{tabular}{|c|c|c|c|c|c|c|c|c|c|c|c|}
\hline \multirow{2}{*}{$\begin{array}{l}\text { Soil Depth } \\
\text { (cm) }\end{array}$} & \multicolumn{3}{|c|}{ Soil Particles Distribution } & \multirow{2}{*}{ Textural Class } & \multirow{2}{*}{$\begin{array}{c}\text { Field Capacity } \\
(\%)\end{array}$} & \multirow{2}{*}{$\begin{array}{c}\text { Wilting Point } \\
(\%)\end{array}$} & \multirow{2}{*}{$\begin{array}{l}\text { Bulk Density } \\
\qquad\left(\mathrm{g} \mathrm{cm}^{-3}\right)\end{array}$} & \multirow{2}{*}{$\begin{array}{c}\text { Calcium Carbonate } \\
(\%)\end{array}$} & \multirow{2}{*}{$\begin{array}{c}\text { Organic Matter } \\
(\%)\end{array}$} & \multirow{2}{*}{$\mathrm{pH} *$} & \multirow{2}{*}{$\begin{array}{c}\mathrm{EC} \\
\left(\mathrm{dS} \mathrm{m}^{-1}\right)\end{array}$} \\
\hline & Sand $(\%)$ & Silt (\%) & Clay $(\%)$ & & & & & & & & \\
\hline $0-30$ & 48.19 & 13.83 & 37.98 & Sandy clay & 13.50 & 6.75 & 1.48 & 0.41 & 0.46 & 7.96 & 1.63 \\
\hline $30-60$ & 47.99 & 13.76 & 38.25 & Sandy clay & 12.31 & 6.15 & 1.51 & 0.41 & 0.34 & 7.90 & 1.60 \\
\hline $60-90$ & 48.02 & 13.69 & 38.29 & Sandy clay & 12.20 & 6.10 & 1.53 & 0.40 & 0.32 & 7.90 & 1.56 \\
\hline \multirow{2}{*}{$\begin{array}{l}\text { Soil Depth } \\
\quad \text { (cm) }\end{array}$} & \multicolumn{8}{|c|}{ Soluble Cations and Anions $\left(\operatorname{mmolc} \mathrm{L}^{-1}\right) * *$} & \multicolumn{3}{|c|}{ Available Nutrient (mg kg ${ }^{-1}$ Soil) } \\
\hline & Calcium & Magnesium & Sodium & Potassium & Carbonate & Bicarbonate & Chloride & Sulphate & Nitrogen & Phosphorus & Potassium \\
\hline $0-30$ & 5.54 & 4.65 & 3.07 & 2.90 & 0 & 6.57 & 3.94 & 5.65 & 20.02 & 11.00 & 170.00 \\
\hline $30-60$ & 5.53 & 4.58 & 3.09 & 2.70 & 0 & 6.33 & 4.97 & 4.60 & 17.50 & 9.25 & 154.00 \\
\hline $60-90$ & 5.47 & 4.40 & 3.11 & 2.68 & 0 & 6.07 & 4.98 & 4.61 & 16.70 & 9.00 & 143.20 \\
\hline
\end{tabular}




\subsubsection{Experimental Design and Treatments}

Spraying treatments were allocated into main plots in a split-plot design with three replicates, while soil nitrogen fertilization levels were allocated into subplots. After determining available soil $\mathrm{N}$ in both seasons, the required amount of $\mathrm{N}$ fertilizer was calculated to reach the required soil nitrogen fertilization levels, i.e., $145,180,215$, and $250 \mathrm{~kg} \mathrm{ha}^{-1}$. The calculated $\mathrm{N}$ amounts were applied as ammonium nitrate $(33.5 \% \mathrm{~N})$ in three splits, $15 \%, 50 \%$, and $35 \%$ at sowing, growth stage (GS)22, and GS 32, respectively [44]. Each sub plot area was $20 \mathrm{~m}^{2}(4 \times 5 \mathrm{~m})$. Plots were surrounded by wide borders $(0.75 \mathrm{~m})$ to prevent nutrients' movement between plots.

Foliar spraying treatments, i.e., control, WPH solution $\left(2 \mathrm{~g} \mathrm{~L}^{-1}\right)$ and urea solution $\left(10 \mathrm{~g} \mathrm{~L}^{-1}\right)$, were applied to wheat plants with the same concentrations at GS 25 , GS 35, and GS 60 [44], using a hand-operated compressed air sprayer. The volume of spraying solution per plot was almost 5 and $6 \mathrm{~L}$ for the first and other application times, respectively. This volume was adequate to completely wet the plot's plant.

\subsubsection{Crop Management}

Wheat (Triticum aestivum L. cv. Shandaweel 1) was sown on 15 November after maize as a preceding crop in both seasons. Sowing was conducted in rows $15 \mathrm{~cm}$ apart using a seeding rate of 400 seeds $\mathrm{m}^{-2}$. Before sowing, $15.5 \mathrm{~kg} \mathrm{P}_{2} \mathrm{O}_{5} \mathrm{ha}^{-1}$ and $24 \mathrm{~kg} \mathrm{~K}_{2} \mathrm{O}$ ha ${ }^{-1}$ were added. The other agricultural practices were applied as recommended for growing wheat in the study region. Harvesting was achieved during the third week of April in both seasons.

\subsubsection{Field Measurements}

At heading (GS 59), 10 flag leaves were selected randomly to estimate flag leaf area using the formula (length $x$ maximum width $\times 0.80$ ) according to Voldeng and Simpson [45]. Total chlorophyll content (SPAD value) was measured using Minolta SPAD-502 chlorophyll meter at heading, as an average of 30 readings conducted on flag leaves.

At harvest, 10 spikes were randomly selected from each subplot to estimate: fertile spikelets number spike ${ }^{-1}$, grain number spike ${ }^{-1}$, and grain weight spike ${ }^{-1}(\mathrm{~g})$; grains were weighted after air-drying to $14 \%$ moisture content. Thousand-grain weight $(\mathrm{g})$ was estimated as a weighted average of three random samples of 1000 grains from each plot. At harvest, plants were collected from one guarded square meter from each plot to estimate spike number $\mathrm{m}^{-2}$, grain, and straw yields $\left(\mathrm{kg} \mathrm{m}^{-2}\right)$ then converted into ha. Harvest index $(\%)$ was calculated as the ratio of grain yield divided by above ground biomass.

\subsubsection{N Accumulation Measurements}

Ten random shoots were collected from each plot at maturity to determine grain and straw $\mathrm{N}$ content $\left(\mathrm{mg} \mathrm{g}^{-1}\right)$. The shoot samples were separated into two components (grains and straw) and dried at $70{ }^{\circ} \mathrm{C}$ until constant weight. Then, wet digestion was carried out using a mixture of $\mathrm{HClO}_{4}$ and $\mathrm{H}_{2} \mathrm{SO}_{4}$. The micro-Kjeldahl method was used to determine the $\mathrm{N}$ content. The following parameters were calculated:

$$
\text { Grain protein content }=\text { grain } \mathrm{N} \text { content } \times 5.71
$$

$$
\text { Grain } \mathrm{N} \text { uptake }(\mathrm{kg} / \mathrm{ha})=\text { grain yield } \times \text { grain } \mathrm{N} \text { content }
$$

Total $\mathrm{N}$ uptake $(\mathrm{kg} / \mathrm{ha})=($ grain yield $\times$ grain $\mathrm{N}$ content $)+($ straw yield $\times$ straw $\mathrm{N}$ content $)$

$$
\begin{gathered}
\mathrm{N} \text { utilization efficiency }(\mathrm{kg} / \mathrm{kg})=\text { grain yield } \div \text { total } \mathrm{N} \text { uptake } \\
\mathrm{N} \text { harvest index }=(\text { grain } \mathrm{N} \text { uptake } \div \text { Total } \mathrm{N} \text { uptake }) \times 100
\end{gathered}
$$

Partial factor productivity $(\mathrm{PFP})$ of applied $\mathrm{N}(\mathrm{kg}$ grain $/ \mathrm{kg} \mathrm{N})=$ grain yield $\div$ amount of applied $\mathrm{N}$. 


\subsubsection{Statistical Analysis}

The experimental data were subjected to split-plot analysis. The least significant difference test (LSD) at $p \leq 0.05$ was used to compare treatment means. To better describe the influence of increasing $\mathrm{N}$ levels on the investigated parameters, ANOVA were divided into linear, quadratic, and deviations from regression. The response curves of grain yield to nitrogen fertilization levels for the three spraying treatments and the prediction of optimum grain yield and nitrogen level were performed using GraphPad Prism program (version 5.00, GraphPad Inc., San Diego, CA, USA). Principal component analysis (PCA) was performed using Factoextra package in R statistical software (version 3.6.1, R Foundation for Statistical Computing, Vienna, Austria).

\section{Results}

\subsection{Whey Protein Hydrolysate Characterization}

At $37^{\circ} \mathrm{C}$ and $\mathrm{pH} 6$, buffalo whey protein was hydrolyzed with papain (enzyme/substrate ratio 1:200), for time periods ranging from 1 to $3 \mathrm{~h}$. The degrees of hydrolysis (DH) for the obtained hydrolysates were calculated, and the results are shown in Figure 1A. The $\mathrm{DH}$ of buffalo whey protein hydrolysate obtained after 1,2 , and $3 \mathrm{~h}$ were $10 \%, 16 \%$, and $25 \%$, respectively.

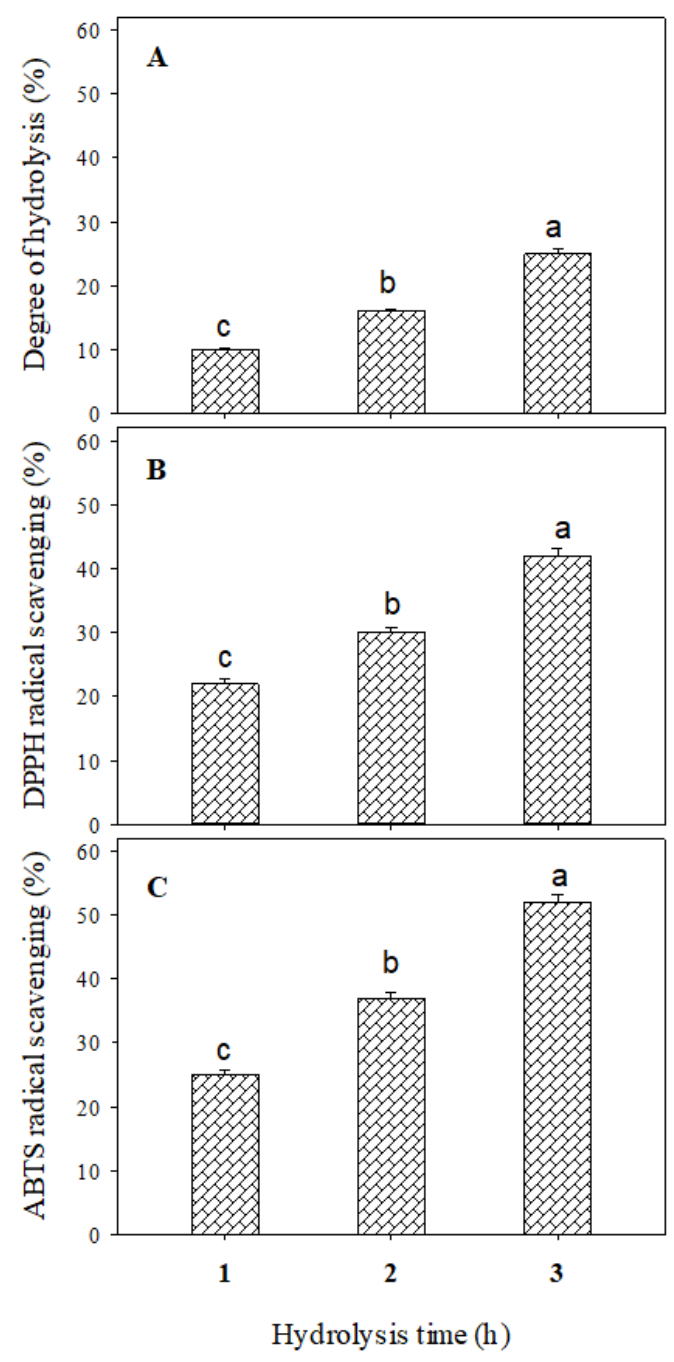

Figure 1. (A) Degree of hydrolysis (\%), (B) DPPH-radical scavenging (\%), and (C) ABTS-radical scavenging (\%) of whey protein hydrolyzed with papain for different periods $(1,2$, and $3 \mathrm{~h})$. Data are expressed as the mean \pm SE. Different superscript letters $(a, b$, and $c)$ in the same box refer to significant differences. 
DPPH radical scavenging activities of buffalo whey protein with different DH were estimated (Figure 1B). Papain released peptides from Buffalo whey protein, which increased its DPPH radical scavenging activity from 22 to $42 \%$, when increasing the time of hydrolysis from 1 to $3 \mathrm{~h}$, in parallel with the increase of the DH from 10 to $25 \%$. Antioxidants are well known for interacting with free radicals and forming stable species, stopping oxidation. The results showed that the released peptides were an excellent electron donor, capable of reacting with free radicals to break the radical chain reaction. Similarly, ABTS radical scavenging activities of buffalo whey hydrolysates (Figure 1C) increased from 25 to 52\%, coinciding with a $\mathrm{DH}$ of 10 and $25 \%$, respectively.

The peptides released in the $3 \mathrm{~h}$ papain-produced hydrolysates were analyzed by electro-spray-ionization-MS (ESI-MS) for molecular weight determination, peptides identification. The main peaks are presented in Figure 2. The hydrolysate was composed on 10 peptides with the molecular masses ranging from $158.84 \mathrm{Da}$ to $452.95 \mathrm{Da}$. It included six dipeptides with molecular masses in the range of 158.84 Da to 339.23 Da with the following possible amino acid constitution: AS, SC, GH, EY, CY, and YC, for peptide numbers 1, 2, $3,4,5$, and 6 , respectively. It included also three tripeptides with the molecular masses of $393.33,403.53$, and 407.07 Da, respectively, and one tetrapeptide with a molecular mass of $452.95 \mathrm{Da}$. Generally, it can be stated that papain hydrolysate of buffalo whey protein is characterized by a limited number of released peptides (10 peptides). It can be realized that two thirds of the amino acids forming the dipeptides are hydrophobic, i.e., $3 \mathrm{Y}$ (tyr), $3 \mathrm{C}$ (cys), $1 \mathrm{~A}$ (ala) and $1 \mathrm{G}$ (gly), in accordance with the specific preference of papain to cleave peptide bonds at the hydrophobic amino acids. Only one basic amino acid residue, i.e., $\mathrm{H}$ (his), was involved in the dipeptides.

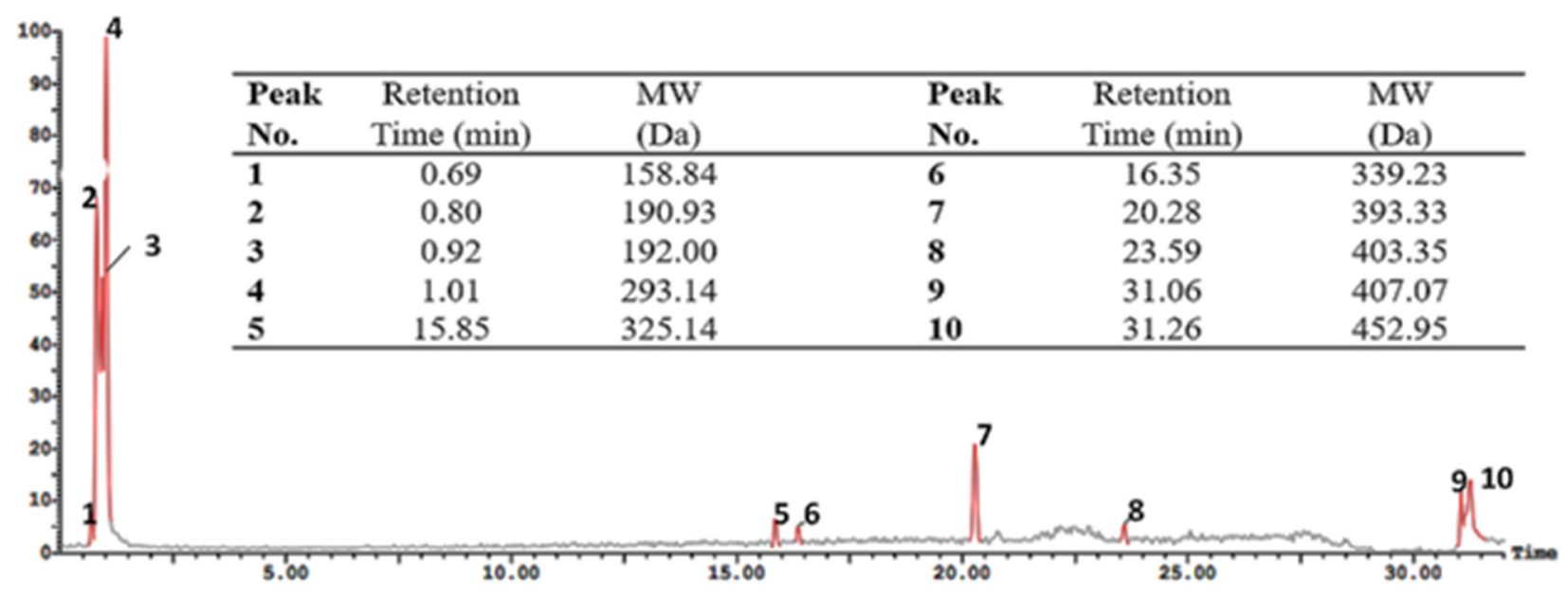

Figure 2. Chromatogram of peptides formation from whey protein hydrolyzed with papain.

The known preference of papain towards the basic amino acid residues may be stronger than that towards the hydrophobic amino acids residues, resulting in a bigger relative amount of free basic amino acids (Table 3 ).

The data in Table 3 present the concentrations of the free amino acids ( $\mathrm{g} / 100 \mathrm{~g}$ total free amino acids) released from the papain hydrolysis after $3 \mathrm{~h}$. It is clearly seen that the basic amino acid constitutes the highest proportion of the free amino acids (35.35\%) and also a high proportion of the hydrophobic amino acid (19.00\%), i.e., their sum constitutes more than $50 \%$ of the papain-released free amino acids. This is probably due to the preference of papain to cleave peptide bonds of basic and hydrophobic amino acids. The hydrophilic amino acids are also released at about $31 \%$, referring to the broad specificity of that enzyme. 
Table 3. Free amino acids concentrations ( $\mathrm{g} / 100 \mathrm{~g}$ total. free amino acids) of whey protein hydrolysate.

\begin{tabular}{|c|c|c|}
\hline Amino Acid & Conc (g/100 g) & Relative Content \\
\hline \multicolumn{3}{|l|}{ Basic amino acids } \\
\hline Lysine & 2.2 & \multirow{4}{*}{$35.35 \%$} \\
\hline Arginine & 19.4 & \\
\hline Histidine & 11.7 & \\
\hline Total & 33.3 & \\
\hline \multicolumn{3}{|l|}{ Acidic amino acids } \\
\hline Aspartic & 10 & \multirow{3}{*}{$14.22 \%$} \\
\hline Glutamic & 3.4 & \\
\hline Total & 13.4 & \\
\hline \multicolumn{3}{|c|}{ Aromatic amino acids } \\
\hline Tyrosine & 2.1 & \multirow{3}{*}{$4.45 \%$} \\
\hline Phenylalanine & 2.1 & \\
\hline Total & 4.2 & \\
\hline \multicolumn{3}{|c|}{ Hydrophobic amino acids } \\
\hline Glycine & 3.5 & \multirow{9}{*}{$19.00 \%$} \\
\hline Alanine & 2.4 & \\
\hline Valine & 2.2 & \\
\hline Leucine & 2.5 & \\
\hline Isoleucine & 2.3 & \\
\hline Tyrosine & 2.1 & \\
\hline Phenylalanine & 2.1 & \\
\hline Methionine & 0.8 & \\
\hline Total & 17.9 & \\
\hline \multicolumn{3}{|c|}{ Hydrophilic amino acids } \\
\hline Serine & 3.4 & \multirow{5}{*}{$31.42 \%$} \\
\hline Threonine & 3 & \\
\hline Asparagine & 20 & \\
\hline Glutamine & 3.2 & \\
\hline Total & 29.6 & \\
\hline
\end{tabular}

Papain is classified as a cysteine protease with preference to basic and hydrophobic amino acid residues. In conclusion, it can be stated that the papain hydrolysate of whey protein was characterized by the dominance of basic amino acids, mostly in free form and the hydrophobic amino acids in both free amin acid forms and dipeptides.

\subsection{Field and N Accumulation Measurements}

Significant differences were noticed among spraying treatments and nitrogen fertilization levels for most of the studied traits and measurements (Tables 4-6). It is obvious from the mean squares of the main effect that $\mathrm{N}$ fertilization levels had more influence than spraying treatments on all measurements, except flag leaf area and $\mathrm{N}$ utilization efficiency in first season as well as grain protein content in both seasons. ANOVA contrasts indicated that all studied measurements showed a significant linear response of $p<0.05$ to increasing $\mathrm{N}$ levels. Moreover, most of these measurements responded quadratically with increasing nitrogen levels, except fertile spikelet number spike ${ }^{-1}$ and straw yield in both seasons, and grain number spike ${ }^{-1}$, grain weight spike ${ }^{-1}, 1000$-grain weight, $\mathrm{N}$ utilization efficiency, as well as partial factor productivity of applied $\mathrm{N}$ in first season, which showed significant linear response only. 


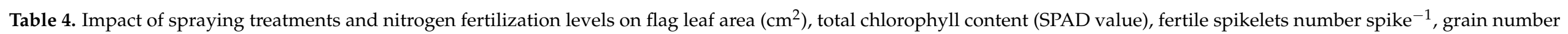
spike $^{-1}$ and grain weight spike ${ }^{-1}$, and 1000-grain weight (g) of wheat during two successive growing seasons of 2017-2018 and 2018-2019.

\begin{tabular}{|c|c|c|c|c|c|c|c|c|c|c|c|c|c|}
\hline \multirow{2}{*}{\multicolumn{2}{|c|}{ Studied Factors }} & \multicolumn{4}{|c|}{ Flag Leaf Area $\left(\mathrm{cm}^{2}\right)$} & \multicolumn{4}{|c|}{ Total Chlorophyll Content (SPAD Value) } & \multicolumn{4}{|c|}{ Fertile Spikelets Number Spike ${ }^{-1}$} \\
\hline & & \multicolumn{2}{|c|}{ 2017-2018 } & \multicolumn{2}{|c|}{ 2018-2019 } & \multicolumn{2}{|c|}{ 2017-2018 } & \multicolumn{2}{|c|}{ 2018-2019 } & \multicolumn{2}{|c|}{$2017-2018$} & \multicolumn{2}{|c|}{ 2018-2019 } \\
\hline \multicolumn{14}{|c|}{ Spraying treatments (S) } \\
\hline \multicolumn{2}{|c|}{ Control } & 34.63 & $\mathrm{C}$ & 38.12 & $\mathrm{C}$ & 49.54 & B & 50.30 & B & 17.05 & & 14.57 & \\
\hline \multicolumn{2}{|c|}{ WPH solution } & 41.61 & A & 44.79 & A & 51.19 & $\mathrm{AB}$ & 52.91 & A & 18.34 & & 15.08 & \\
\hline \multicolumn{2}{|c|}{ Urea solution } & 38.20 & в & 40.41 & B & 51.44 & A & 52.88 & A & 17.61 & & 15.01 & \\
\hline \multicolumn{14}{|c|}{ Nitrogen fertilization levels (N) } \\
\hline \multicolumn{2}{|c|}{$145 \mathrm{~kg} \mathrm{~N} \mathrm{ha}^{-1}$} & 33.63 & c & 35.38 & c & 47.36 & $\mathrm{~b}$ & 47.33 & c & 16.15 & $\mathrm{~b}$ & 12.88 & c \\
\hline \multicolumn{2}{|c|}{$180 \mathrm{~kg} \mathrm{~N} \mathrm{ha}^{-1}$} & 38.10 & $\mathrm{~b}$ & 40.32 & $\mathrm{~b}$ & 51.24 & a & 51.61 & $\mathrm{~b}$ & 17.51 & $\mathrm{ab}$ & 14.19 & $\mathrm{~b}$ \\
\hline \multicolumn{2}{|c|}{$215 \mathrm{~kg} \mathrm{~N} \mathrm{ha}^{-1}$} & 39.89 & a & 43.94 & a & 52.14 & a & 54.47 & a & 18.30 & a & 16.20 & a \\
\hline \multicolumn{2}{|c|}{$250 \mathrm{~kg} \mathrm{~N} \mathrm{ha}^{-1}$} & 40.96 & a & 44.78 & a & 52.14 & a & 54.72 & a & 18.71 & a & 16.28 & a \\
\hline \multirow{2}{*}{ ANOVA } & & \multicolumn{12}{|c|}{ Mean Square (MS) and $p$-Value of Main Effects and Their Interaction ( $p$-Value) } \\
\hline & df & MS & $p$-Value & MS & $p$-Value & MS & $p$-Value & MS & $p$-Value & MS & $p$-Value & MS & $p$-Value \\
\hline S & 2 & 146.05 & 0.005 & 137.74 & $<0.001$ & 12.79 & 0.042 & 26.87 & 0.077 & 5.03 & 0.356 & 0.91 & 0.202 \\
\hline $\mathrm{N}$ & 3 & 94.00 & $<0.001$ & 164.74 & $<0.001$ & 46.73 & $<0.001$ & 106.42 & $<0.001$ & 11.40 & 0.005 & 24.54 & $<0.001$ \\
\hline Linear & 1 & 254.31 & $<0.001$ & 455.50 & $<0.001$ & 104.42 & $<0.001$ & 282.00 & $<0.001$ & 32.19 & 0.002 & 67.10 & $<0.001$ \\
\hline Quadratic & 1 & 25.93 & 0.002 & 37.76 & $<0.001$ & 33.83 & 0.007 & 36.60 & $<0.001$ & 2.01 & 0.355 & 3.42 & 0.197 \\
\hline $\mathrm{S} \times \mathrm{N}$ & 6 & 11.93 & $<0.001$ & 6.80 & 0.001 & 0.142 & 0.039 & 3.42 & 0.02 & 1.85 & 0.472 & 0.89 & 0.704 \\
\hline \multirow{2}{*}{\multicolumn{2}{|c|}{ Studied Factors }} & \multicolumn{4}{|c|}{ Grain Number Spike $^{-1}$} & \multicolumn{4}{|c|}{ Grain Weight Spike ${ }^{-1}$ (g) } & \multicolumn{4}{|c|}{ 1000-Grain Weight (g) } \\
\hline & & \multicolumn{2}{|c|}{$2017-2018$} & \multicolumn{2}{|c|}{ 2018-2019 } & & -2018 & & 2019 & & 2018 & & 2019 \\
\hline Spraying $\mathrm{T}$ & eatme & & & & & & & & & & & & \\
\hline Control & & 27.79 & В & 26.48 & B & 1.14 & B & 1.21 & B & 33.83 & B & 37.35 & В \\
\hline WPH solut & & 30.00 & A & 30.38 & A & 1.34 & $\mathrm{~A}$ & 1.61 & A & 39.01 & A & 44.53 & A \\
\hline Urea soluti & & 30.25 & A & 30.78 & $\mathrm{~A}$ & 1.25 & $\mathrm{AB}$ & 1.29 & B & 36.38 & $\mathrm{AB}$ & 42.55 & $\mathrm{~A}$ \\
\hline Nitrogen F & rtiliza & els (N) & & & & & & & & & & & \\
\hline $145 \mathrm{~kg} \mathrm{~N} \mathrm{~h}$ & & 27.33 & c & 20.96 & c & 1.00 & c & 0.80 & c & 30.03 & c & 34.35 & c \\
\hline $180 \mathrm{~kg} \mathrm{~N} \mathrm{~h}$ & & 28.12 & $\mathrm{bc}$ & 26.2 & $\mathrm{~b}$ & 1.17 & $\mathrm{~b}$ & 1.27 & $\mathrm{~b}$ & 33.64 & $\mathrm{~b}$ & 41.11 & $\mathrm{~b}$ \\
\hline $215 \mathrm{~kg} \mathrm{~N} \mathrm{~h}$ & & 30.38 & $\mathrm{ab}$ & 34.32 & a & 1.38 & a & 1.69 & a & 39.71 & a & 44.70 & a \\
\hline $250 \mathrm{~kg} \mathrm{~N} \mathrm{~h}$ & & 31.56 & $\mathrm{a}$ & 35.36 & a & 1.42 & a & 1.73 & a & 42.25 & a & 45.75 & a \\
\hline
\end{tabular}


Table 4. Cont.

\begin{tabular}{|c|c|c|c|c|c|c|c|c|c|c|c|c|c|}
\hline \multirow{2}{*}{\multicolumn{2}{|c|}{ Studied Factors }} & \multicolumn{4}{|c|}{ Flag Leaf Area $\left(\mathrm{cm}^{2}\right)$} & \multicolumn{4}{|c|}{ Total Chlorophyll Content (SPAD Value) } & \multicolumn{4}{|c|}{ Fertile Spikelets Number Spike ${ }^{-1}$} \\
\hline & & \multicolumn{2}{|c|}{ 2017-2018 } & \multicolumn{2}{|c|}{ 2018-2019 } & \multicolumn{2}{|c|}{ 2017-2018 } & \multicolumn{2}{|c|}{ 2018-2019 } & \multicolumn{2}{|c|}{ 2017-2018 } & \multicolumn{2}{|c|}{ 2018-2019 } \\
\hline \multirow{2}{*}{ ANOVA } & \multirow{2}{*}{ df } & \multicolumn{12}{|c|}{ Mean Square (MS) and $p$-Value of Main Effects and Their Interaction ( $p$-Value) } \\
\hline & & MS & $p$-Value & MS & $p$-Value & MS & $p$-Value & MS & $p$-Value & MS & $p$-Value & MS & $p$-Value \\
\hline S & 2 & 21.88 & 0.025 & 67.802 & 0.038 & 0.12 & 0.028 & 1.71 & 0.014 & 80.37 & 0.015 & 164.97 & 0.002 \\
\hline $\mathrm{N}$ & 3 & 34.48 & 0.004 & 423.12 & $<0.001$ & 0.34 & $<0.001$ & 0.73 & $<0.001$ & 280.19 & $<0.001$ & 238.74 & $<0.001$ \\
\hline Linear & 1 & 100.20 & $<0.001$ & 1185.03 & $<0.001$ & 0.97 & $<0.001$ & 0.43 & $<0.001$ & 821.88 & $<0.001$ & 642.59 & $<0.001$ \\
\hline Quadratic & 1 & 0.34 & 0.809 & 39.79 & 0.030 & 0.03 & 0.277 & 0.05 & $<0.001$ & 2.53 & 0.582 & 73.47 & 0.002 \\
\hline $\mathrm{S} \times \mathrm{N}$ & 6 & 7.37 & 0.031 & 9.75 & 0.046 & 0.01 & 0.049 & 0.10 & 0.005 & 20.30 & 0.098 & 16.75 & 0.004 \\
\hline
\end{tabular}

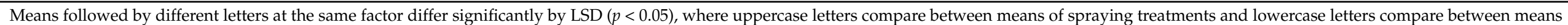
of $\mathrm{N}$ fertilization levels. S: Spraying treatments; $\mathrm{N}$ : nitrogen fertilization levels.

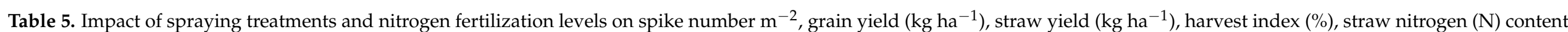
$\left(\mathrm{mg} \mathrm{g}^{-1}\right)$, and grain $\mathrm{N}$ content $\left(\mathrm{mg} \mathrm{g}^{-1}\right)$ of wheat during two successive growing seasons of 2017-2018 and 2018-2019.

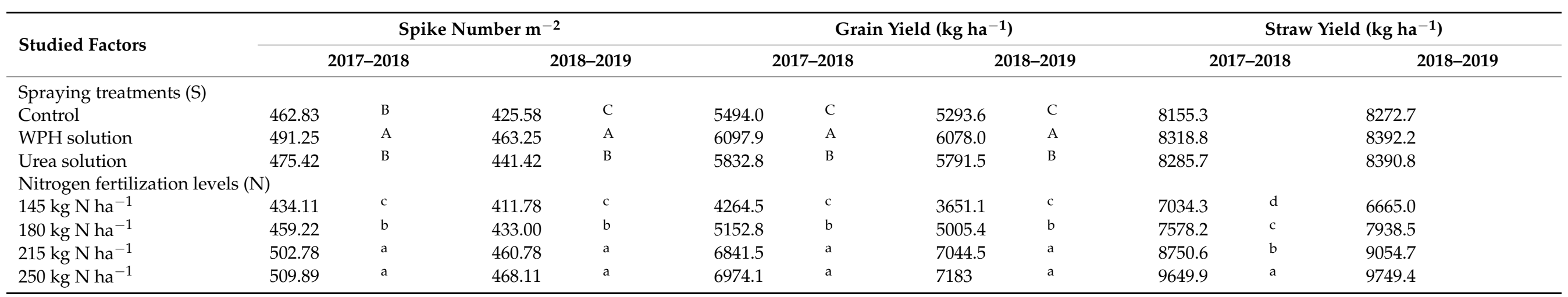


Table 5. Cont.

\begin{tabular}{|c|c|c|c|c|c|c|c|c|c|c|c|c|c|}
\hline \multirow{2}{*}{\multicolumn{2}{|c|}{ Studied Factors }} & \multicolumn{4}{|c|}{ Spike Number $\mathbf{m}^{-2}$} & \multicolumn{4}{|c|}{ Grain Yield (kg ha $\left.{ }^{-1}\right)$} & \multicolumn{4}{|c|}{ Straw Yield $\left(\mathrm{kg} \mathrm{ha}^{-1}\right)$} \\
\hline & & \multicolumn{2}{|c|}{ 2017-2018 } & \multicolumn{2}{|c|}{ 2018-2019 } & \multicolumn{2}{|c|}{ 2017-2018 } & \multicolumn{2}{|c|}{ 2018-2019 } & \multicolumn{2}{|c|}{ 2017-2018 } & \multicolumn{2}{|c|}{ 2018-2019 } \\
\hline ANOVA & df & \multicolumn{12}{|c|}{ Mean Square (MS) and $p$-Value of Main Effects and Their Interaction ( $p$-Value) } \\
\hline S & 2 & 2433.08 & 0.009 & 4292.33 & 0.001 & $1,099,726$ & 0.001 & $1,890,618$ & 0.004 & 89,733 & 0.785 & 56445 & 0.712 \\
\hline $\mathrm{N}$ & 3 & $11,702.05$ & $<0.001$ & 6062.25 & $<0.001$ & $15,718,418$ & $<0.001$ & $26,057,327$ & $<0.001$ & $12,418,396$ & $<0.001$ & $16,390,733$ & $<0.001$ \\
\hline Linear & 1 & $33,021.40$ & $<0.001$ & $17,424.67$ & $<0.001$ & $43,371,168$ & $<0.001$ & $71,837,979$ & $<0.001$ & $36,605,001$ & $<0.001$ & $48,387,202$ & $<0.001$ \\
\hline Quadratic & 1 & 729.00 & 0.016 & 434.03 & $<0.001$ & $1,285,100$ & $<0.001$ & $3,326,111$ & $<0.001$ & 284,172 & 0.176 & 753,547 & 0.103 \\
\hline $\mathrm{S} \times \mathrm{N}$ & 6 & 400.79 & 0.011 & 106.89 & 0.001 & 79,750 & 0.060 & 37,972 & 0.001 & 49,579 & 0.914 & 133,285 & 0.671 \\
\hline \multicolumn{14}{|c|}{ Spraying treatments (S) } \\
\hline Control & & 39.84 & & 37.84 & B & 6.26 & $\mathrm{C}$ & 6.45 & C & 17.40 & В & 18.49 & в \\
\hline WPH solution & & 42.06 & & 41.68 & A & 6.40 & B & 6.55 & B & 19.55 & $\mathrm{~A}$ & 19.00 & A \\
\hline Urea solution & & 41.11 & & 40.48 & A & 6.50 & A & 6.67 & A & 18.81 & A & 19.10 & A \\
\hline \multicolumn{14}{|c|}{ Nitrogen fertilization levels $(\mathrm{N})$} \\
\hline $145 \mathrm{~kg} \mathrm{~N} \mathrm{ha}^{-1}$ & & 37.71 & d & 35.26 & c & 6.17 & c & 6.32 & c & 18.53 & $\mathrm{~b}$ & 18.62 & $\mathrm{~b}$ \\
\hline $180 \mathrm{~kg} \mathrm{~N} \mathrm{ha}^{-1}$ & & 40.48 & c & 38.56 & $\mathrm{~b}$ & 6.24 & $\mathrm{bc}$ & 6.38 & $\mathrm{~b}$ & 19.01 & $\mathrm{ab}$ & 19.03 & a \\
\hline \multirow[t]{2}{*}{$250 \mathrm{~kg} \mathrm{~N} \mathrm{ha}^{-1}$} & & 41.94 & $\mathrm{~b}$ & 42.42 & a & 6.85 & a & 7.08 & a & 18.53 & $\mathrm{~b}$ & 18.59 & $\mathrm{~b}$ \\
\hline & & \multicolumn{2}{|c|}{ 2017-2018 } & \multicolumn{2}{|c|}{ 2018-2019 } & \multicolumn{2}{|c|}{ 2017-2018 } & \multicolumn{2}{|c|}{ 2018-2019 } & \multicolumn{2}{|c|}{ 2017-2018 } & \multicolumn{2}{|c|}{ 2018-2019 } \\
\hline \multirow{2}{*}{ ANOVA } & \multirow{2}{*}{ df } & \multicolumn{12}{|c|}{ Mean square (MS) and $p$-value of main effects and their interaction ( $p$-value) } \\
\hline & & MS & $p$-Value & MS & $p$-Value & MS & $p$-Value & MS & $p$-Value & MS & $p$-Value & MS & $p$-Value \\
\hline S & 2 & 14.90 & 0.165 & 46.26 & 0.003 & 0.17 & $<0.001$ & 0.13 & 0.011 & 21.12 & 0.018 & 1.29 & $<0.001$ \\
\hline $\mathrm{N}$ & 3 & 60.93 & $<0.001$ & 133.81 & $<0.001$ & 0.87 & $<0.001$ & 1.10 & $<0.001$ & 1.98 & 0.046 & 0.85 & $<0.001$ \\
\hline Linear & 1 & 116.98 & $<0.001$ & 320.49 & $<0.001$ & 1.94 & $<0.001$ & 2.42 & $<0.001$ & 1.36 & $<0.001$ & 0.12 & 0.049 \\
\hline Quadratic & 1 & 49.95 & $<0.001$ & 48.66 & $<0.001$ & 0.57 & $<0.001$ & 0.75 & $<0.001$ & 4.57 & $<0.001$ & 2.43 & $<0.001$ \\
\hline Deviations & 1 & 15.869 & 0.027 & 32.29 & 0.003 & 0.12 & $<0.001$ & 0.15 & $<0.001$ & 0.01 & 0.177 & 0.003 & 0.613 \\
\hline $\mathrm{S} \times \mathrm{N}$ & 6 & 1.811 & 0.034 & 21.99 & $<0.001$ & 0.002 & 0.034 & 0.001 & 0.048 & 0.16 & 0.041 & 0.01 & 0.0306 \\
\hline
\end{tabular}

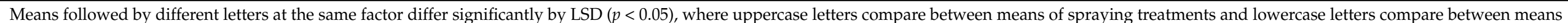
of $\mathrm{N}$ fertilization levels. S: Spraying treatments; N: nitrogen fertilization levels. 


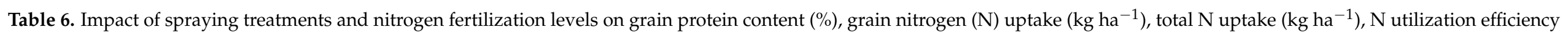

$\left(\mathrm{kg} \mathrm{kg}^{-1}\right)$, N harvest index $(\%)$, and partial factor productivity of applied N $\left(\mathrm{kg} \mathrm{kg}^{-1}\right)$ of wheat during two successive growing seasons of $2017-2018$ and $2018-2019$.

\begin{tabular}{|c|c|c|c|c|c|c|c|c|c|c|c|c|c|}
\hline \multirow{2}{*}{ Studied Factors } & & \multicolumn{4}{|c|}{ Grain Protein Content (\%) } & \multicolumn{4}{|c|}{ Grain N Uptake (kg ha $\left.{ }^{-1}\right)$} & \multicolumn{4}{|c|}{ Total N Uptake (kg ha $\left.{ }^{-1}\right)$} \\
\hline & & \multicolumn{2}{|c|}{ 2017-2018 } & \multicolumn{2}{|c|}{ 2018-2019 } & \multicolumn{2}{|c|}{ 2017-2018 } & \multicolumn{2}{|c|}{ 2018-2019 } & \multicolumn{2}{|c|}{ 2017-2018 } & \multicolumn{2}{|c|}{ 2018-2019 } \\
\hline \multicolumn{14}{|c|}{ Spraying treatments (S) } \\
\hline Control & & 9.93 & в & 10.55 & B & 95.57 & B & 98.04 & $\mathrm{C}$ & 146.92 & B & 151.69 & B \\
\hline WPH solution & & 11.16 & A & 10.85 & A & 119.59 & $\mathrm{~A}$ & 115.61 & $\mathrm{~A}$ & 173.11 & A & 170.96 & A \\
\hline Urea solution & & 11.31 & A & 10.91 & A & 115.83 & A & 110.71 & B & 169.95 & A & 166.95 & A \\
\hline \multicolumn{14}{|c|}{ Nitrogen fertilization levels $(\mathrm{N})$} \\
\hline $145 \mathrm{~kg} \mathrm{~N} \mathrm{ha}^{-1}$ & & 10.58 & $\mathrm{~b}$ & 10.63 & $\mathrm{~b}$ & 79.41 & c & 68.13 & c & 122.90 & c & 110.30 & d \\
\hline $180 \mathrm{~kg} \mathrm{~N} \mathrm{ha}^{-1}$ & & 10.85 & $\mathrm{ab}$ & 10.87 & $\mathrm{ab}$ & 98.13 & $\mathrm{~b}$ & 95.44 & $\mathrm{~b}$ & 145.43 & $\mathrm{~b}$ & 146.15 & c \\
\hline $215 \mathrm{~kg} \mathrm{~N} \mathrm{ha}^{-1}$ & & 11.16 & $\mathrm{a}$ & 10.97 & $\mathrm{a}$ & 133.93 & a & 135.38 & a & 188.95 & $\mathrm{a}$ & 193.74 & $\mathrm{~b}$ \\
\hline $250 \mathrm{~kg} \mathrm{~N} \mathrm{ha}^{-1}$ & & 10.62 & $\mathrm{~b}$ & 10.61 & $\mathrm{~b}$ & 129.87 & a & 133.54 & a & 196.03 & a & 202.61 & a \\
\hline \multirow{2}{*}{ ANOVA } & \multirow{2}{*}{ df } & \multicolumn{12}{|c|}{ Mean Square (MS) and $p$-Value of Main Effects and Their Interaction ( $p$-Value) } \\
\hline & & MS & $p$-Value & MS & $p$-Value & MS & $p$-Value & MS & $p$-Value & MS & $p$-Value & MS & $p$-Value \\
\hline S & 2 & 6.88 & 0.042 & 0.42 & $<0.001$ & 2002.81 & 0.003 & 986.84 & $<0.001$ & 2452.27 & 0.004 & 1239.33 & 0.002 \\
\hline $\mathrm{N}$ & 3 & 0.64 & $<0.001$ & 0.28 & $<0.001$ & 6131.06 & $<0.001$ & 9446.82 & $<0.001$ & $11,042.86$ & $<0.001$ & $16,724.94$ & $<0.001$ \\
\hline Linear & 1 & 0.98 & 0.041 & 0.24 & 0.024 & $15,767.82$ & $<0.001$ & $25,096.65$ & $<0.001$ & $31,106.57$ & $<0.001$ & $47,390.6$ & $<0.001$ \\
\hline Quadratic & 1 & 0.85 & 0.042 & 0.59 & $<0.001$ & 1166.53 & $<0.001$ & 1912.05 & $<0.001$ & 537.38 & 0.004 & $31,638.06$ & $<0.001$ \\
\hline $\mathrm{S} \times \mathrm{N}$ & 6 & 0.05 & 0.039 & 0.003 & 0.041 & 18.60 & 0.032 & 120.94 & $<0.001$ & 31.56 & 0.041 & 94.26 & 0.028 \\
\hline \multirow{2}{*}{\multicolumn{2}{|c|}{ Studied Factors }} & \multicolumn{4}{|c|}{$\begin{array}{l}\text { N Utilization Efficiency } \\
\left(\mathrm{kg} \mathrm{kg}^{-1}\right)\end{array}$} & \multicolumn{4}{|c|}{$\begin{array}{c}\text { N Harvest Index } \\
(\%)\end{array}$} & \multicolumn{4}{|c|}{$\begin{array}{l}\text { Partial Factor Productivity of Applied N (kg } \\
\left.\mathrm{kg}^{-1}\right)\end{array}$} \\
\hline & & \multicolumn{2}{|c|}{ 2017-2018 } & \multicolumn{2}{|c|}{ 2018-2019 } & 201 & -2018 & \multicolumn{2}{|c|}{ 2018-2019 } & 201 & 018 & \multicolumn{2}{|c|}{ 2018-2019 } \\
\hline \multicolumn{6}{|c|}{ Spraying treatments (S) } & & & & & & & & \\
\hline Control & & 37.19 & & 34.15 & & 64.68 & B & 63.19 & B & 49.56 & B & 45.61 & B \\
\hline WPH solution & & 35.24 & & 35.48 & & 68.86 & A & 67.43 & A & 55.05 & A & 54.14 & A \\
\hline Urea solution & & 34.34 & & 34.56 & & 67.95 & A & 66.03 & A & 42.84 & C & 42.00 & B \\
\hline \multicolumn{14}{|c|}{ Nitrogen fertilization levels $(\mathrm{N})$} \\
\hline $145 \mathrm{~kg} \mathrm{~N} \mathrm{ha}^{-1}$ & & 34.77 & & 32.89 & $\mathrm{~d}$ & 64.37 & c & 61.30 & c & 60.17 & a & 51.12 & a \\
\hline $180 \mathrm{~kg} \mathrm{~N} \mathrm{ha}^{-1}$ & & 35.55 & & 34.19 & c & 67.35 & $\mathrm{~b}$ & 65.11 & $\mathrm{~b}$ & 48.47 & $\mathrm{~b}$ & 47.18 & $\mathrm{~b}$ \\
\hline $215 \mathrm{~kg} \mathrm{~N} \mathrm{ha}^{-1}$ & & 36.38 & & 36.38 & a & 70.76 & a & 69.88 & a & 48.44 & $\mathrm{~b}$ & 49.86 & $\mathrm{~b}$ \\
\hline $250 \mathrm{~kg} \mathrm{~N} \mathrm{ha}^{-1}$ & & 35.66 & & 35.46 & $\mathrm{~b}$ & 66.16 & $\mathrm{~b}$ & 65.92 & $\mathrm{~b}$ & 39.53 & c & 40.71 & c \\
\hline
\end{tabular}


Table 6. Cont

\begin{tabular}{|c|c|c|c|c|c|c|c|c|c|c|c|c|c|}
\hline \multirow{2}{*}{ Studied Factors } & & \multicolumn{4}{|c|}{ Grain Protein Content (\%) } & \multicolumn{4}{|c|}{ Grain N Uptake (kg ha $\left.{ }^{-1}\right)$} & \multicolumn{4}{|c|}{ Total N Uptake (kg ha $\left.{ }^{-1}\right)$} \\
\hline & & \multicolumn{2}{|c|}{ 2017-2018 } & \multicolumn{2}{|c|}{ 2018-2019 } & \multicolumn{2}{|r|}{ 2017-2018 } & \multicolumn{2}{|c|}{ 2018-2019 } & \multicolumn{2}{|c|}{ 2017-2018 } & \multicolumn{2}{|c|}{ 2018-2019 } \\
\hline \multirow{2}{*}{ ANOVA } & \multirow{2}{*}{ df } & \multicolumn{12}{|c|}{ Mean Square (MS) and $p$-Value of Main Effects and Their Interaction ( $p$-Value) } \\
\hline & & MS & $p$-Value & MS & $p$-Value & MS & $p$-Value & MS & $p$-Value & MS & $p$-Value & MS & $p$-Value \\
\hline S & 2 & 25.39 & 0.076 & 5.55 & 0.034 & 57.73 & 0.0112 & 55.88 & 0.003 & 448.48 & 0.002 & 458.05 & 0.009 \\
\hline $\mathrm{N}$ & 3 & 3.84 & 0.108 & 20.78 & $<0.001$ & 65.40 & $<0.001$ & 111.53 & $<0.001$ & 644.86 & $<0.001$ & 194.05 & $<0.001$ \\
\hline Linear & 1 & 5.95 & 0.005 & 43.98 & $<0.001$ & 34.65 & 0.006 & 156.16 & $<0.001$ & 1726.71 & $<0.001$ & 367.41 & $<0.001$ \\
\hline Quadratic & 1 & 5.46 & 0.006 & 11.12 & 0.001 & 129.44 & $<0.001$ & 136.08 & $<0.001$ & 17.55 & 0.051 & 61.19 & 0.009 \\
\hline $\mathrm{S} \times \mathrm{N}$ & 6 & 1.87 & 0.305 & 7.51 & 0.061 & 1.06 & 0.041 & 25.81 & $<0.001$ & 33.66 & $<0.001$ & 58.34 & $<0.001$ \\
\hline
\end{tabular}

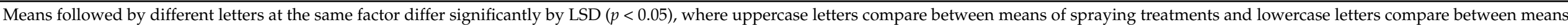
of $\mathrm{N}$ fertilization levels. S: Spraying treatments; $\mathrm{N}$ : nitrogen fertilization levels. 
Generally, increasing $\mathrm{N}$ fertilization level from 145 up to $215 \mathrm{~kg} \mathrm{~N}$ ha $^{-1}$ was accompanied by significant increases in all yield traits and $\mathrm{N}$ accumulation measurements, except for the partial factor productivity of applied nitrogen, which decreased (Tables 4-6). Increasing the $\mathrm{N}$ fertilization rate from 145 to $215 \mathrm{~kg} \mathrm{~N} \mathrm{ha}^{-1}$ increased the average two-season grain yield by about $80 \%$ and the straw yield by about $20 \%$. In the first season, the grain yield significantly increased from 4264.5 to 5152.8 and $6841.5 \mathrm{~kg} \mathrm{ha}^{-1}$ when increasing the level of $\mathrm{N}$ fertilization from 145 to 180 and $215 \mathrm{~kg} \mathrm{~N} \mathrm{ha}^{-1}$, respectively. Similar corresponding values were recorded in the second season, i.e., $3651.1,5005.4$, and $7044.5 \mathrm{~kg} \mathrm{ha}^{-1}$, respectively (Table 5). Similarly, the grain N uptake significantly increased from 79.41, 98.13 and $133.93 \mathrm{~kg} \mathrm{ha}^{-1}$, in the first season and $68.13,95.44$ and $135.38 \mathrm{~kg} \mathrm{ha}^{-1}$, when increasing the level of $\mathrm{N}$ fertilization from 145 to 180 and $215 \mathrm{~kg} \mathrm{~N}$ ha $^{-1}$, respectively (Table 6). Further increasing the soil $\mathrm{N}$ fertilization to more than 215 and up to $250 \mathrm{~kg} \mathrm{~N} \mathrm{ha}^{-1}$ did not result in any significant increases in grain yield, its attributes, and grain $\mathrm{N}$ uptake in both seasons, in addition to total $\mathrm{N}$ uptake in the first season, and only significantly increased straw yield and straw $\mathrm{N}$ content in both seasons. Moreover, this high level of soil $\mathrm{N}$ fertilization led to significant decreases in grain $\mathrm{N}$ content, grain protein content, partial factor productivity of applied $\mathrm{N}$ and $\mathrm{N}$ harvest index in both seasons, and $\mathrm{N}$ utilization efficiency in the second season (Tables 5 and 6).

Urea foliar application (15 $\mathrm{kg} \mathrm{N} \mathrm{ha}^{-1}$ ) improved flag leaf area, total chlorophyll content (SPAD value), grain number spike, spike number $\mathrm{m}^{-2}$, and grain yield in both seasons in addition to the harvest index in the second season compared to control treatment. WPH foliar application $\left(1 \mathrm{~kg} \mathrm{~N} \mathrm{ha}^{-1}\right)$ increased flag leaf area, grain number spike ${ }^{-1}$, grain weight spike ${ }^{-1}, 1000$-grain weight, spike number $\mathrm{m}^{-2}$, and grain yield in both seasons, in addition to total chlorophyll content (SPAD value) and harvest index in the second season, compared to control treatment (Tables 4 and 5).

Treating wheat plants with foliar spray of WPH or urea enhanced plant growth parameters and yield traits more than control (Tables 4 and 5). The impact of WHP ( $\left.1 \mathrm{~kg} \mathrm{~N} \mathrm{ha}^{-1}\right)$ was more pronounced than urea $\left(15 \mathrm{~kg} \mathrm{~N} \mathrm{ha}^{-1}\right)$ and was very close to the impact of soil fertilization at high levels (215-250 $\left.\mathrm{kg} \mathrm{N} \mathrm{ha}^{-1}\right)$. A similar magnitude of effect was also found on all $\mathrm{N}$ accumulation indicators in both seasons compared with untreated plants (Tables 5 and 6).

The interaction effect between spraying treatments and $\mathrm{N}$ fertilization levels is presented in Figures 3-5. WPH foliar application improved flag leaf area, total chlorophyll content (SPAD value), 1000-grain weight, spike number $\mathrm{m}^{-2}$, grain yield, and $\mathrm{N}$ harvest index under all $\mathrm{N}$ fertilization levels compared to control treatment. WPH foliar application produced more flag leaf area, spike number ${ }^{-2}$, and grain yield than urea foliar application under all $\mathrm{N}$ fertilization levels, except for grain yield under $145 \mathrm{~kg} \mathrm{~N}^{-1}$ fertilization level, where the increase did not reach the level of significance $(p<0.05)$.

Treating plants with WPH or urea enhanced total chlorophyll content (SPAD value), grain number spike ${ }^{-1}$, grain weight spike ${ }^{-1}$, and harvest index under limited $\mathrm{N}$ conditions of 145 and $180 \mathrm{~kg} \mathrm{~N} \mathrm{ha}^{-1}$ compared with untreated plants.

Regarding $\mathrm{N}$ accumulation measurements, foliar spraying with WPH or urea increased grain $\mathrm{N}$ content, straw $\mathrm{N}$ content, grain protein content, grain $\mathrm{N}$ uptake, andtotal $\mathrm{N}$ uptake under all $\mathrm{N}$ fertilization levels compared with control treatment. WPH application enhanced partial factor productivity of applied $\mathrm{N}$ at 145,185 , and $215 \mathrm{~kg} \mathrm{~N}^{-1}$ fertilization levels compared to control treatment. The interaction results highlighted the positive role of WPH in improving grain yield and partial factor productivity of applied N, exhibiting a more efficient NUE indicator under relative steady-state cropping systems. 

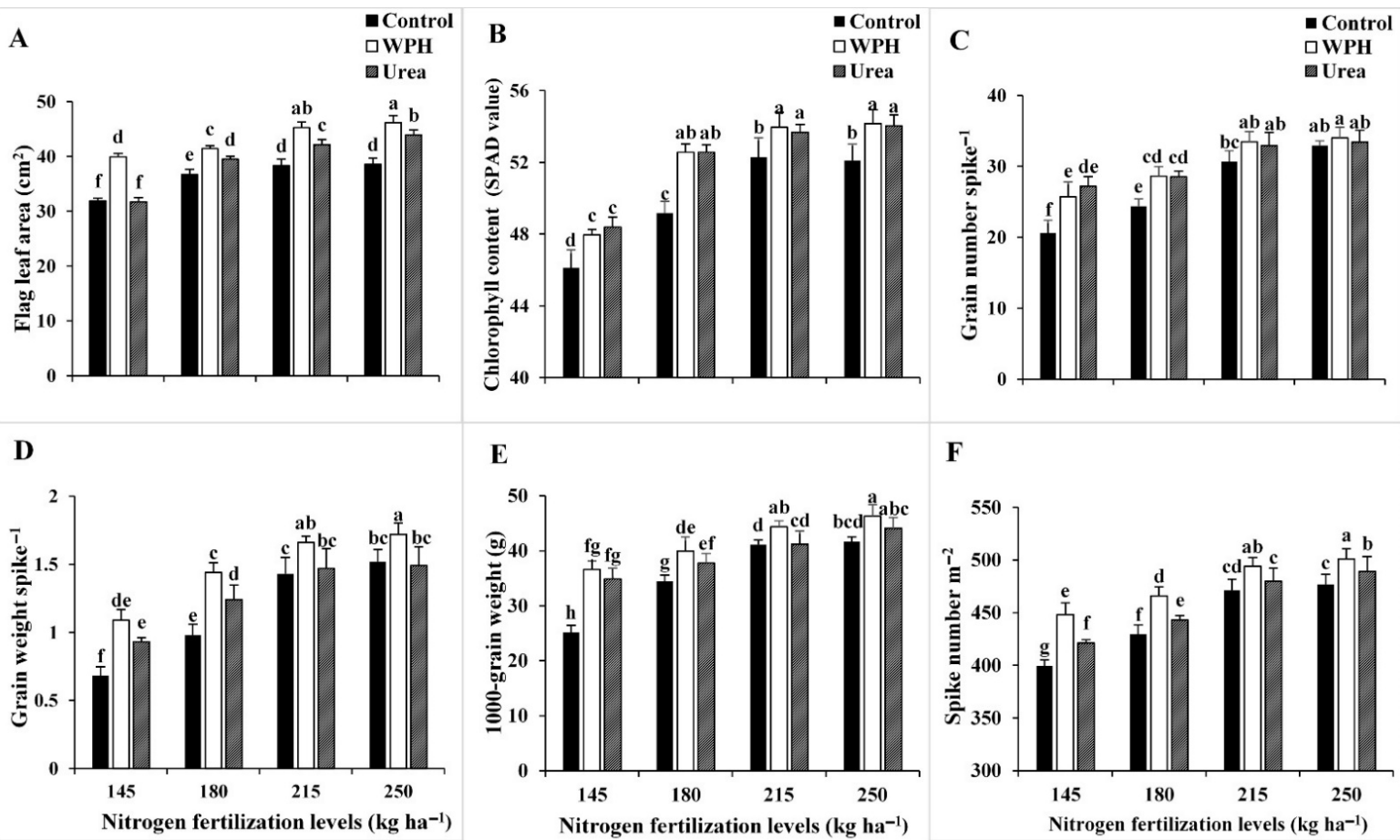

F

Figure 3. Interaction effect between spraying treatments and nitrogen fertilization levels on flag leaf area $\left(\mathrm{cm}^{2}\right)$, total chlorophyll content (SPAD value), grain number spike ${ }^{-1}$ and grain weight spike ${ }^{-1}, 1000$-grain weight (g), and spike number $\mathrm{m}^{-2}$ of wheat grown and averaged over the two growing seasons of 2017-2018 and 2018-2019 ((A-F), respectively). The bars on the top of the columns represent the standard error of means and different letters on the column differ significantly by LSD $(p<0.05)$.
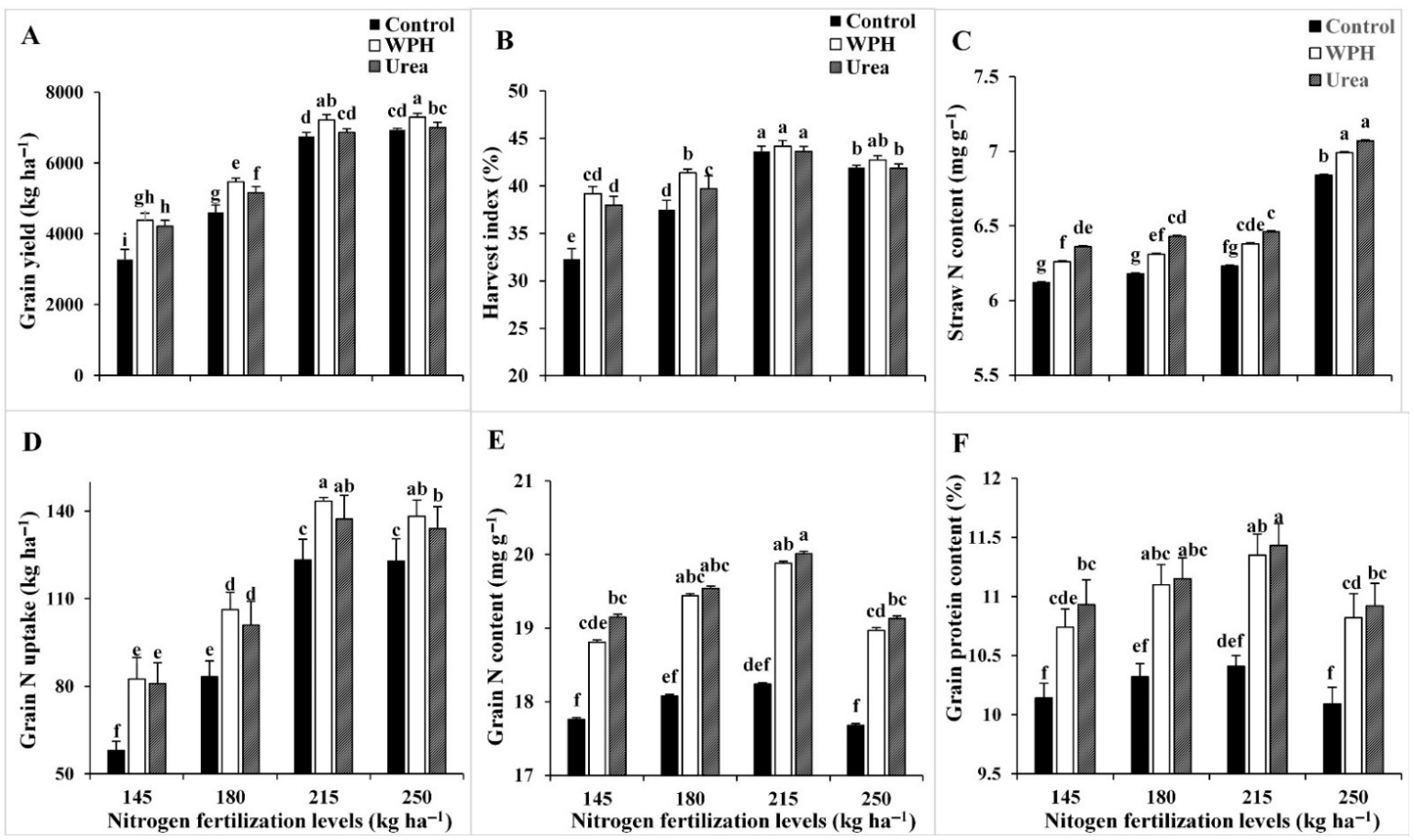

Figure 4. Interaction effect between spraying treatments and nitrogen fertilization levels on grain yield (kg ha $\left.{ }^{-1}\right)$, harvest index $(\%)$, straw nitrogen $(\mathrm{N})$ content $\left(\mathrm{mg} \mathrm{g}^{-1}\right)$, grain $\mathrm{N}$ uptake $\left(\mathrm{kg} \mathrm{ha}^{-1}\right)$, grain $(\mathrm{N})$ content $\left(\mathrm{mg} \mathrm{g}^{-1}\right)$, and grain protein content (\%) of wheat averaged over two the growing seasons of 2017-2018 and 2018-2019 (A-F), respectively. The bars on the top of the columns represent the standard error of means and different letters on the columns differ significantly by LSD $(p<0.05)$. 

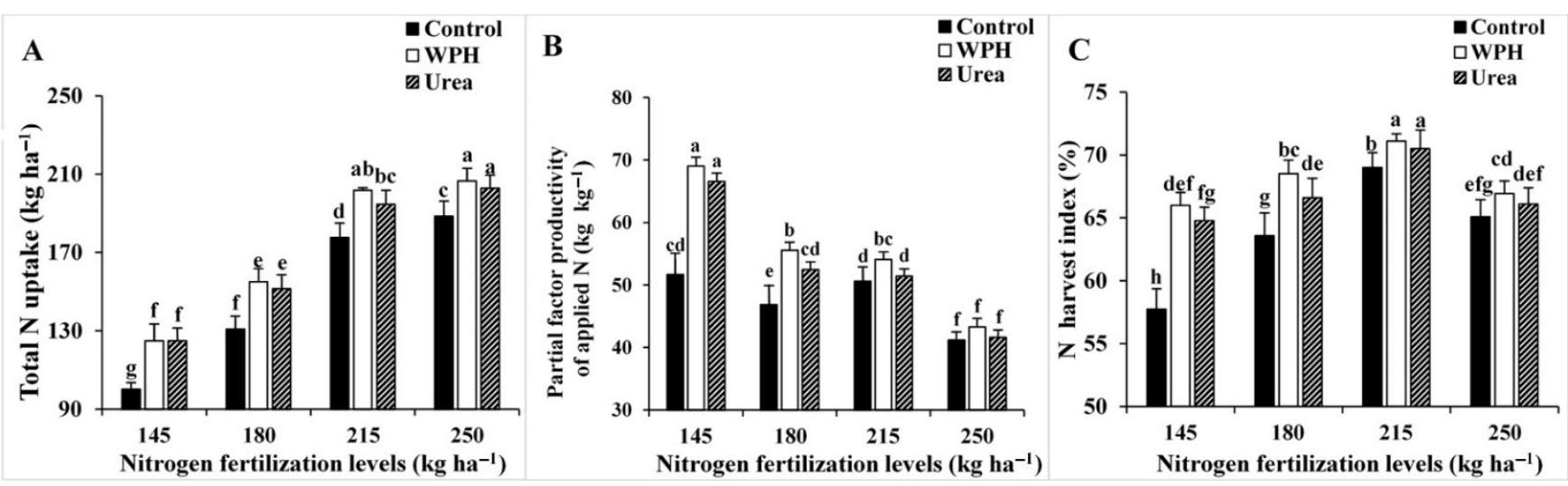

Figure 5. Interaction effect between spraying treatments and nitrogen fertilization levels on total nitrogen (N) uptake (kg $\left.\mathrm{ha}^{-1}\right)$, partial factor productivity of applied $\mathrm{N}\left(\mathrm{kg} \mathrm{kg}^{-1}\right)$, and $\mathrm{N}$ harvest index (\%) of wheat averaged over the two growing seasons of 2017-2018 and 2018-2019 (A-C), respectively. The bars on the top of the columns represent the standard error of means and different letters on the columns differ significantly by LSD $(p<0.05)$.

Comparing the additive impact of foliar spray with WPH $\left(1.0 \mathrm{~kg} \mathrm{~N} \mathrm{ha}^{-1}\right)$ and urea (15 kg N ha ${ }^{-1}$ ) to plants cultivated at two levels (low and high) of soil $\mathrm{N}$ fertilization (145 and $215 \mathrm{~kg} \mathrm{~N} \mathrm{ha}^{-1}$ ) has given the data presented in Figure 6. It can be observed that wheat plants yield at the low level of soil $\mathrm{N}$ fertilization $\left(145 \mathrm{~kg} \mathrm{~N} \mathrm{ha}^{-1}\right)$ was highly improved by both WPH and urea foliar spray, where the associated relative increases in plant grain yield amounted to 36.1 and $30.9 \%$ over the control, respectively. Alternatively, the corresponding relative increases at the high soil $\mathrm{N}$ fertilization level $\left(215 \mathrm{~kg} \mathrm{~N} \mathrm{ha}^{-1}\right)$ were relatively low, i.e., 8.5 and $2.8 \%$ over the control, respectively. So, the influence of the foliar spray is maximal when the level of soil $\mathrm{N}$ fertilization is low. Foliar spray in such case is compensating the shortage of soil $\mathrm{N}$ fertilization. It can also be observed that the additive impact of WPH is superior to urea at the two levels of soil $\mathrm{N}$ fertilization although the level of urea foliar spray is 15 times that of WPH. So, it can be concluded that the potentially stimulating impact of WPH on the different physiological processes of wheat plants may explain this superiority.

On the other hand, the influence of foliar spray with WPH $\left(1.0 \mathrm{~kg} \mathrm{~N} \mathrm{ha}^{-1}\right)$ and urea $\left(15 \mathrm{~kg} \mathrm{~N} \mathrm{ha}^{-1}\right)$ on the cultivated wheat plants was higher relative increases in grain protein content at the high level of soil $\mathrm{N}$ fertilization $\left(215 \mathrm{~kg} \mathrm{~N} \mathrm{ha}^{-1}\right)$, amounting to 8.6 and $9.4 \%$ over the respective control.

\subsection{Response of Grain Yield and Grain Protein Content to Nitrogen Fertilization Levels}

Figure 7 describes the impact of spraying treatments on the response of grain yield and grain protein content to $\mathrm{N}$ fertilization levels using regression model. The response curves displayed quadratic convex diminishing response. The predicted optimum nitrogen amount for control, spraying with WPH, and spraying with urea were 235.99, 235.56, and $236.56 \mathrm{~kg} \mathrm{~N} \mathrm{ha}^{-1}$, which could produce $6845.15,7255.12$, and $6934.32 \mathrm{~kg}$ grains ha ${ }^{-1}$, respectively. Regarding the response of grain protein content to nitrogen fertilization levels, the predicted optimum nitrogen levels for control and spraying with WPH or urea were $146.55,168.65$, and $172.5 \mathrm{~kg} \mathrm{~N} \mathrm{ha}^{-1}$, which could enhance grain protein content to 10.14 , 11.09 , and $11.18 \%$, respectively. These results highlighted the efficacy of WPH in increasing grain yield and grain protein content and rationalizing the use of nitrogenous fertilizers compared to control treatment, particularly under low $\mathrm{N}$ fertilization levels. 


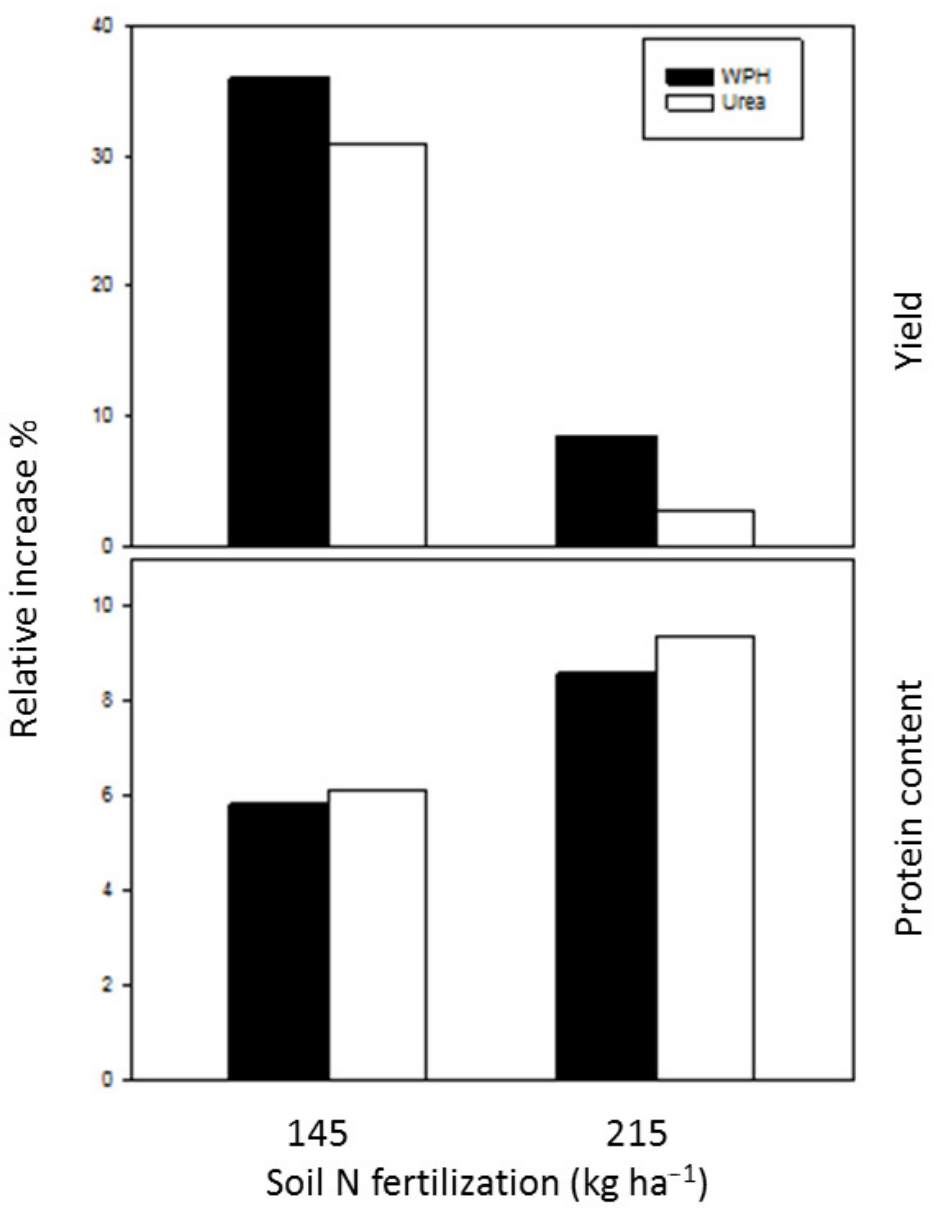

Figure 6. Relative increases (\%) in grain yield and protein content of wheat grown under two nitrogen fertilization levels (145 and $215 \mathrm{~kg} \mathrm{ha}^{-1}$ ) averaged over the two growing seasons of 2017-2018 and 2018-2019.
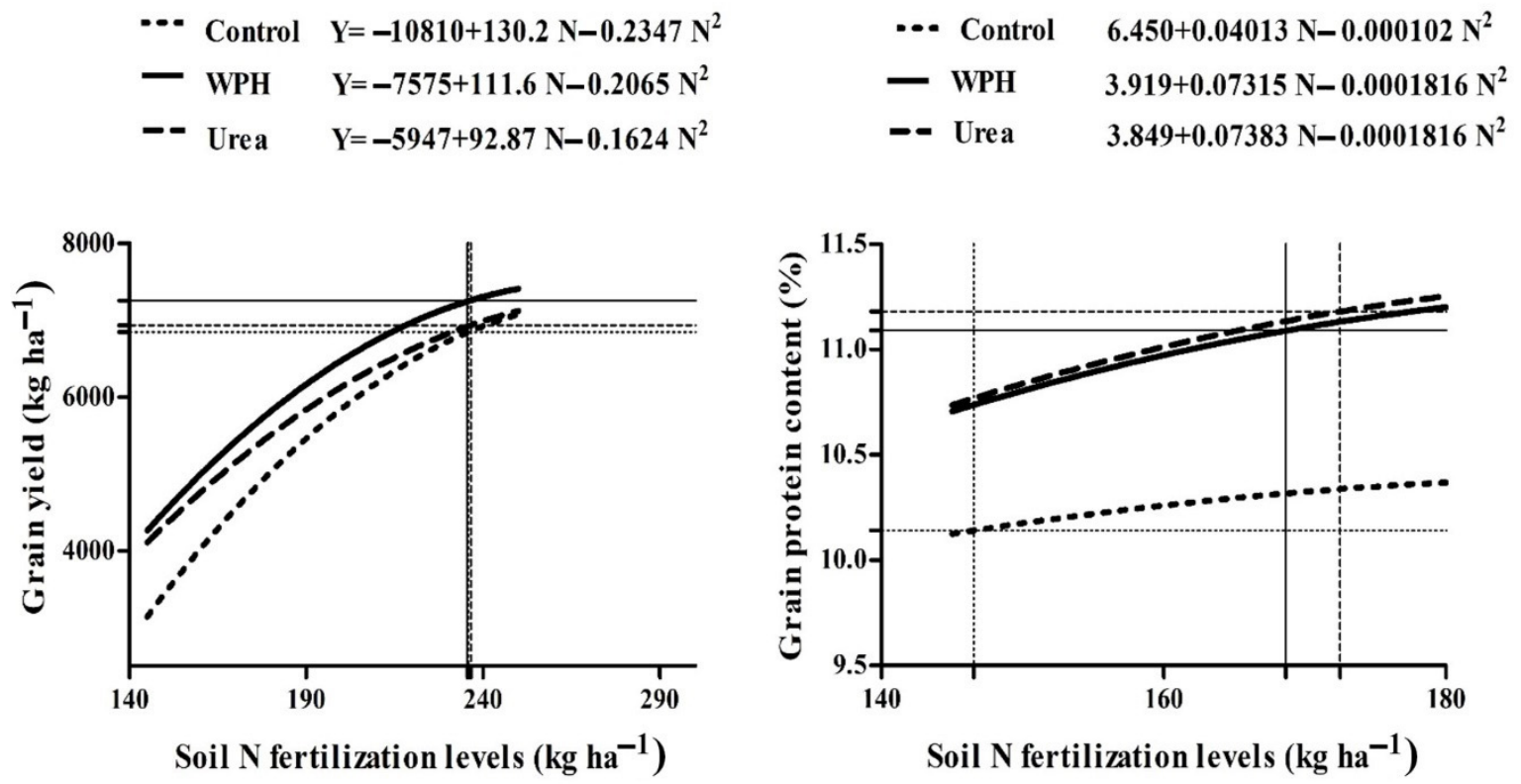

Figure 7. Response of wheat grain yield and grain protein to nitrogen fertilization levels as affected by spraying treatments over the two growing seasons based on the interaction data. The dotted vertical lines display the optimum nitrogen fertilization levels, and horizontal lines display the expected grain yield for each spraying treatment. 
Therefore, WPH could be used for improving wheat grain yield, grain protein content, as well as partial factor productivity of applied N, as a more efficient NUE indicator under relative steady-state cropping systems.

\subsection{Interrelationship among Measured Traits}

The interrelationships among yield, attributes, and nitrogen accumulation measurements were estimated using the principal component analysis (PCA) and presented in Figure 8. The PCA consists of two principal components (component 1 and component 2) that account for $74.22 \%$ of the variance. The longer the vectors in PCA, the higher the variance it will have. The higher variable invariances are grain yield, grain $\mathrm{N}$ content, grain protein content, grain $\mathrm{N}$ uptake, and total $\mathrm{N}$ uptake. The lower variable invariances are fertile spikelets number spike ${ }^{-1}$, straw $\mathrm{N}$ content, partial factor productivity of applied $\mathrm{N}$, and $\mathrm{N}$ harvest index. The other variables are in the same length and the same degree of variation. The degree of the angle among the vectors of the variables displays the correlation among them. The closer the angle, the higher the correlation that will result. The biplot demonstrated a strong positive association between flag leaf area, total chlorophyll content, fertile spikelets number spike ${ }^{-1}$, grain number spike ${ }^{-1}$, grain weight spike ${ }^{-1}$, 1000-grain weight, spike number $\mathrm{m}^{-2}$, grain yield, straw yield, harvest index, straw $\mathrm{N}$ content, grain $\mathrm{N}$ uptake, total $\mathrm{N}$ uptake, $\mathrm{N}$ utilization efficiency, and $\mathrm{N}$ harvest index. The toward sides vectors $\left(\right.$ at $90^{\circ}$ ) reveal a weak association between the variables. Hence, there was a weak relationship between grain yield, grain $\mathrm{N}$, and protein content. The vectors placed approximately opposite (at $180^{\circ}$ ) present a highly negative correlation. So, a negative correlation emerged between partial factor productivity of applied $\mathrm{N}$ and all measurements of yield and $\mathrm{N}$ accumulation, except grain $\mathrm{N}$ and protein content.

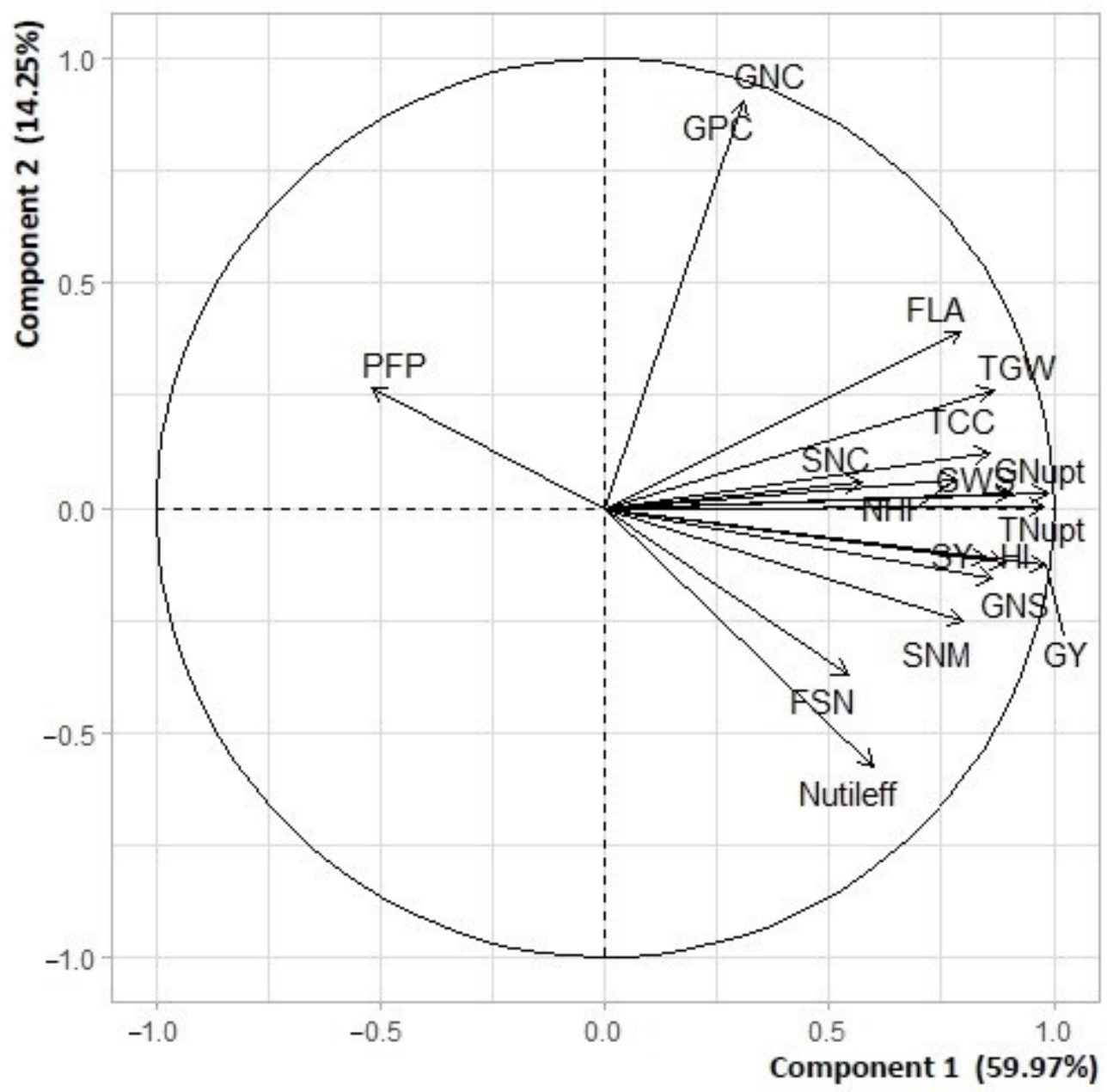

Figure 8. Biplot of principal components for the studied yield, its attributes, and $\mathrm{N}$ accumulation measurements of wheat 
grown under three spraying treatments and four nitrogen fertilization levels over the two growing seasons of 2017-2018 and 2018-2019. FLA is flag leaf area, TCC is total chlorophyll content (SPAD value), FSN is fertile spikelets number spike ${ }^{-1}$, GNS is grain number spike ${ }^{-1}$, GWS is grain weight spike ${ }^{-1}$, TGW is 1000-grain weight, SNM is spike number ${ }^{-2}$, GY is grain yield, SY is straw yield, HI is harvest index, GNC is grain nitrogen content, SNC is straw nitrogen content, GPC is grain protein content, GNupt is grain nitrogen uptake, TNupt is total nitrogen uptake, Nutileff is nitrogen utilization efficiency, PFP is partial factor productivity of applied N, and NHI is nitrogen harvest index.

\section{Discussion}

Plants require $\mathrm{N}$ to build their photosynthetically active canopy and in the formation of its yield components [5]. Furthermore, cereal crops require $\mathrm{N}$ for protein synthetase, which is stored in grains [5]. $\mathrm{N}$ fertilization is one of the agriculture procedures most influencing wheat growth, development, and productivity. The global demand for mineral fertilizers has increased in the last few years, especially nitrogenous fertilizers. The expected increase in the global demand for $\mathrm{N}$ will increase by about $6.13 \%$ in 2022 compared to the global $\mathrm{N}$ demands in 2016 [46]. Nitrogenous fertilizers are the most expensive fertilizer used, so they increase production costs if their prices are shifted up. So, optimizing $\mathrm{N}$ fertilization may enable achieving high yield with high quality. Mansour et al. [7] found that spike number $\mathrm{m}^{-2}$, grain number spike ${ }^{-1}, 1000$ grain weight, grain nitrogen content, and $\mathrm{N}$ utilization efficiency showed significant quadratic response to nitrogen levels, while straw $\mathrm{N}$ content and $\mathrm{N}$ uptake efficiency showed linear response to $\mathrm{N}$ levels.

Results revealed that the increasing $\mathrm{N}$ fertilization level from $145 \mathrm{~kg} \mathrm{~N} \mathrm{ha}^{-1}$ up to $215 \mathrm{~kg} \mathrm{~N} \mathrm{ha}^{-1}$ was accompanied by a significant increase in all yield traits and $\mathrm{N}$ accumulation measures, except for partial factor productivity of applied $\mathrm{N}$, which decreased. The results are in harmony with those obtained by $[1,2,7,47]$. Correspondingly, no significant increase was observed in grain yield, its attributes, and grain $\mathrm{N}$ uptake in both seasons as well as total $\mathrm{N}$ uptake in first season due to increasing $\mathrm{N}$ fertilization level from $215 \mathrm{~kg} \mathrm{~N}^{-1}$ up to $250 \mathrm{~kg} \mathrm{~N} \mathrm{ha}^{-1}$; while it decreased grain $\mathrm{N}$ content, grain protein content, partial factor productivity of applied N, and $\mathrm{N}$ harvest index in both seasons. Wang et al. [48] reported that the excessive $\mathrm{N}$ application decreased grain yield, $\mathrm{N}$ uptake, and internal $\mathrm{N}$ use efficiency. Kong et al. [49] found that the excessive use of $\mathrm{N}$ promoted reactive oxygen species (ROS) accumulation and decreased ROS scavenging ability, inducing distributions in $\mathrm{N}$ metabolism, leading to decreased wheat grain filling and yield. Moreover, Tabak et al. [1] deduced that the unsuitable management or excessive use of nitrogen fertilization reduced wheat yield, increased $\mathrm{N}$ losses and the consequent incidence of environmental threats, and minimized the economic profits of wheat production.

Urea foliar application was found to be an efficient method of $\mathrm{N}$ fertilization in wheat [12,18]. Saleem et al. [17] deduced that urea foliar application can be integrated with the soil application of $\mathrm{N}$ to fulfill wheat $\mathrm{N}$ requirements under available $\mathrm{N}$ limitation. Urea foliar application significantly improved all $\mathrm{N}$ accumulation parameters, flag leaf area, total chlorophyll content (SPAD value), grain number spike ${ }^{-1}$, and grain yield in both seasons. Admittedly, most wheat yield attributes can be improved by foliar urea application but the time of application determines the yield attribute. In the current investigation, urea was sprayed thrice at tillering, stem elongation, and anthesis stages. It was deduced that the pre-anthesis application increased spike number $\mathrm{m}^{-2}$ and grain number spike $\mathrm{e}^{-1}$ and grain yield $[14,15,18,50]$. Alternatively, it was reported that the application at and post anthesis enhanced grain yield and bread making quality. In addition, Saleem et al. [17] found that urea foliar application increased grain $\mathrm{N}$ content and $\mathrm{N}$ uptake. These results assured the positive role of urea foliar application in improving wheat yield and grain protein content.

One of the study objectives was to evaluate the influence of whey protein hydrolysates produced by papain (WPH) on grain yield, yield attributes, and $\mathrm{N}$ uptake compared with control and urea treatment. Results revealed that WPH foliar application increased all $\mathrm{N}$ accumulation parameters, flag leaf area, total chlorophyll content (SPAD value), grain number and weight spike ${ }^{-1}, 1000$-grain weight, spike number $\mathrm{m}^{-2}$, and grain yield in both seasons compared to control treatment (Tables 4-6). Moreover, WPH foliar application 
achieved more flag leaf area, spike number $\mathrm{m}^{-2}$, and grain yield than urea foliar application (Tables 4 and 5).

Schiavon et al. [51] assured that protein hydrolysates $(\mathrm{PH})$ application promoted the activities of enzymes involved in carbon (C) metabolism as well as $\mathrm{N}$ reduction and assimilation, which had a positive influence on the conversion of inorganic $\mathrm{N}$ derived from fertilizers into organic N. Colla et al. [24] attributed the positive influence of protein hydrolysates on plant growth to the stimulation of $\mathrm{N}$ uptake and assimilation. Furthermore, Colla et al. [23] speculated that the increase in $\mathrm{N}$ assimilation may be attributed to the increase in $\mathrm{C}$ assimilation and production of the energy involved in amino acids synthesis. Also, they added that $\mathrm{PH}$ improved nutrient uptake by enhancing soil microbial activity, improving mobility and solubility of micronutrients, and improving root architecture. Sestili et al. [52] added that the activation of enzymes involved in $\mathrm{C}$ and $\mathrm{N}$ metabolism by $\mathrm{PH}$ may support plant performance and productivity. Moreover, $\mathrm{PH}$ has a plant growthregulating influence due to its content of peptides [24], which may cause the increase in flag leaf area. Colla et al. [24] found that PH increased maize leaf $\mathrm{N}$ content and total chlorophyll content (SPAD value) by about $21.5 \%$ and $15 \%$ compared to untreated plants, respectively. The increase in flag leaf area and total chlorophyll content enhanced the photosynthesis efficiency of wheat plant (Table 5). Colla et al. [23] noted that $\mathrm{PH}$ improved sink-source relationships by improving photosynthesis efficiency and enhancing the synthases translocation to the sinks.

Heat stress during the grain filling period is one of the main constraints to wheat production under Mediterranean conditions [53]. Gurav and Jadhav [54] reported that $\mathrm{PH}$ application increased the accumulation of proline and other antioxidant compounds such as flavonoids and polyphenols. Consequently, WPH may play a role in alleviating heat stress effects during wheat grain filling period, causing a significant increase in grain weight spike ${ }^{-1}$ (Table 4). The ABTS+ radical scavenging activity assay has been commonly used as an antioxidant activity assay for lipophilic and hydrophilic compounds [55]. The results indicating enhanced ABTS radical scavenging activities by the increased magnitude of released peptides support their role in different related antioxidant activities. A similar conclusion was reached by Foh et al. [56] and You et al. [57].

The impact of the interaction between spraying treatments (WPH and Urea) and the levels of soil $\mathrm{N}$ fertilization indicated that WPH foliar application has the capability to increase flag leaf area, total chlorophyll content (SPAD value), 1000-grain weight, spike number $\mathrm{m}^{-2}$, grain yield, and $\mathrm{N}$ harvest index under all $\mathrm{N}$ fertilization levels compared to control treatment. Besides, WPH foliar application was more effective than urea in producing more flag leaf area, spike number ${ }^{-2}$, and grain yield than under all $\mathrm{N}$ fertilization levels, except for grain yield under $145 \mathrm{~kg} \mathrm{~N} \mathrm{ha}^{-1}$ fertilization level, where the increase did not reach the level of significance $(p<0.05)$. At soil $\mathrm{N}$ fertilization level $\left(145 \mathrm{~kg} \mathrm{~N} \mathrm{ha}^{-1}\right)$, the relative increases in grain proteins were only 5.8 and $6.1 \%$ over the respective control. This may indicate that grain protein content is very dependent upon the level of $\mathrm{N}$ fertilization, either through soil application or foliar spray. This is particularly true, since urea treatment $\left(15 \mathrm{~kg} \mathrm{~N} \mathrm{ha}^{-1}\right)$ excelled in WPH treatment $\left(1 \mathrm{~kg} \mathrm{~N} \mathrm{ha}^{-1}\right)$ in this action due to the higher level of $\mathrm{N}$ application in the first case.

These results reflect the efficacy of WPH in improving grain yield. The obtained findings agree with those of Moreno-Hernández et al. [58] who assured that PHs, as bio stimulant compounds, can stimulate physiological processes in plants, enhancing crop yield, quality, and alleviating abiotic stress impacts.

The results refer to a strong positive association between flag leaf area, total chlorophyll content, fertile spikelets number spike ${ }^{-1}$, grain number spike ${ }^{-1}$, grain weight spike ${ }^{-1}$, 1000-grain weight, spike number $\mathrm{m}^{-2}$ grain yield, straw yield, harvest index, straw $\mathrm{N}$ content, grain $\mathrm{N}$ uptake, total $\mathrm{N}$ uptake, $\mathrm{N}$ utilization efficiency, and the $\mathrm{N}$ harvest index. Fageria [59] revealed that the $\mathrm{N}$ harvest index is a very important yield indicator, which measures $\mathrm{N}$ partitioning in crop plants and reflects the efficiency of the crop plants in utilizing the absorbed $\mathrm{N}$ for grain production. He referred to the presence of a positive as- 
sociation between grain yield and the $\mathrm{N}$ harvest index. On the other hand, Triboi et al. [60] demonstrated a strong negative relationship between grain yield and grain $\mathrm{N}$ and protein content.

The response curves of grain yield to $\mathrm{N}$ fertilization levels displayed a quadratic convex diminishing response in accordance with Dobermann [11], who reported a mutual increase in the crop yield and nutrient accumulation/uptake by plants in parallel with increasing the amount of nutrients applied to reach a peak point and then diminishing after that point. Similarly, Mansour et al. [7] demonstrated a quadratic relationship between grain yield and $\mathrm{N}$ fertilization levels. The response curves revealed the role of WPH in increasing the grain yield compared to control, particularly under low $\mathrm{N}$ fertilization levels. According to WPH response equation, WPH could produce the same predicted grain yield of control treatment by adding $213.77 \mathrm{~kg} \mathrm{~N} \mathrm{ha}^{-1}$ and saving about $22.22 \mathrm{~kg} \mathrm{~N} \mathrm{ha}^{-1}$ (5.99\% of predicted $\mathrm{N}$ requirements). In addition, it could produce the same predicted grain yield of urea treatment using $217.68 \mathrm{~kg} \mathrm{~N} \mathrm{ha}^{-1}$ and saving about $18.88 \mathrm{~kg} \mathrm{~N} \mathrm{ha}^{-1}$ ( $4.63 \%$ of predicted $\mathrm{N}$ requirements). Furthermore, WPH response equation detected that $122 \mathrm{~kg} \mathrm{~N} \mathrm{ha}^{-1}$ is needed to produce the same grain protein content of control treatment, saving $24 \mathrm{~g} \mathrm{~N} \mathrm{ha}^{-1}(16.82 \%$ of $\mathrm{n}$ requirements). Evidently, the response curves revealed the role of WPH in increasing the optimum grain yield and rationalizing the use of nitrogenous fertilizers compared to control, particularly under low $\mathrm{N}$ fertilization levels. MorenoHernández et al. [57] reported that protein hydrolysates offer a promising tool to reduce agrochemical use and increase crop productivity.

\section{Conclusions}

The current WPH (whey protein hydrolysate) treatment represents an efficient approach that can enhance both wheat grain yield and nitrogen use efficiency (NUE), counteracting the low yield typically obtained under a Mediterranean arid environment. The foliar spray of WPH is an efficient method positively influencing wheat yield and quality. Increasing soil nitrogen $(\mathrm{N})$ fertilization up to $215 \mathrm{~kg} \mathrm{~N} \mathrm{ha}^{-1}$ increased all yield traits and $\mathrm{N}$ accumulation measurements, except partial factor productivity of applied $\mathrm{N}$, which decreased. No further significant increases were noticed in grain yield, attributes, and grain $\mathrm{N}$ uptake in both seasons, and total $\mathrm{N}$ uptake when increasing $\mathrm{N}$ fertilization level from $215 \mathrm{~kg} \mathrm{~N}$ ha $^{-1}$ up to $250 \mathrm{~kg} \mathrm{~N} \mathrm{ha}^{-1}$. WPH increased $\mathrm{N}$ accumulation in wheat plants, grain yield, most of the yield attributes, and partial factor productivity of applied nitrogen as an NUE indicator compared to control treatment. WPH improved flag leaf area, spike number $\mathrm{m}^{-2}$, and grain yield compared to urea foliar application as evidenced by tracing the relationship between grain yield and $\mathrm{N}$ fertilization levels by the quadratic regression model. Results highlighted the efficacy of PWPH in increasing yield and NUE. Farmers can reduce the rate of soil nitrogen fertilization by incorporating a safe spray of whey protein hydrolysates.

Author Contributions: Conceptualization, A.O., A.M.E.-S. and M.S.; methodology, A.O., A.M.E.-S. and S.M.A.I.A.-S.; software, A.A.E.-Y. and H.G.A.E.-G.; validation, A.O., A.M.E.-S. and M.S.; formal analysis, E.A. and A.A.G.; investigation, M.S.; resources, A.M.E.-S.; data curation, A.O.; writingoriginal draft preparation, A.O., A.M.E.-S. and S.M.A.I.A.-S.; writing-review and editing, M.S.; visualization, E.A.; supervision, M.S. All authors have read and agreed to the published version of the manuscript.

Funding: This research received no external funding.

Data Availability Statement: Data are available on request.

Acknowledgments: We thank Taif University Researchers Supporting Project number (TURSP2020/13), Taif University, Taif, Saudi Arabia. The authors thank El-Sayed Mansour for his valuable help in regression statistical analysis.

Conflicts of Interest: The authors declare no conflict of interest. 


\section{References}

1. Tabak, M.; Lepiarczyk, A.; Filipek-Mazur, B.; Lisowska, A. Efficiency of nitrogen fertilization of winter wheat depending on sulfur fertilization. Agronomy 2020, 10, 1304. [CrossRef]

2. Xu, A.; Li, L.; Xie, J.; Wang, X.; Coulter, J.A.; Liu, C.; Wang, L. Effect of long-term nitrogen addition on wheat yield, nitrogen use efficiency, and residual soil nitrate in a semiarid area of the loess plateau of China. Sustainability 2020, 12, 1735. [CrossRef]

3. Arzani, A.; Ashraf, M. Cultivated ancient wheats (Triticum spp.): A potential source of health-beneficial food products. Compr. Rev. Food Sci. Food Saf. 2017, 16, 477-488. [CrossRef] [PubMed]

4. Wu, W.; Ma, B. Integrated nutrient management (INM) for sustaining crop productivity and reducing environmental impact: A review. Sci. Total Environ. 2015, 512, 415-427. [CrossRef]

5. Hawkesford, M.J. Reducing the reliance on nitrogen fertilizer for wheat production. J. Cereal Sci. 2014, 59, 276-283. [CrossRef]

6. Randive, K.; Raut, T.; Jawadand, S. An overview of the global fertilizer trends and India's position in 2020. Miner. Econ. 2021, 34, 371-384. [CrossRef]

7. Mansour, E.; Merwad, A.M.A.; Yasin, M.A.T.; Abdul-Hamid, M.I.E.; El-Sobky, E.E.A.; Oraby, H.F. Nitrogen use efficiency in spring wheat: Genotypic variation and grain yield response under sandy soil conditions. J. Agric. Sci. 2017, 155, 1407-1423. [CrossRef]

8. Omara, P.; Aula, L.; Oyebiyi, F.; Raun, W.R. World cereal nitrogen use efficiency trends: Review and current knowledge. Agrosyst. Geosci. Environ. 2019, 2, 1-8. [CrossRef]

9. López-Bellido, L.; López-Bellido, R.J.; López-Bellido, F.J. Fertilizer nitrogen efficiency in durum wheat under rainfed Mediterranean conditions: Effect of split application. Agron. J. 2006, 98, 55-62. [CrossRef]

10. Ma, B.; Qian, W.; Yuan, C.; Yuan, Z.; Peng, Y. Achieving mainstream nitrogen removal through coupling anammox with denitratation. Environ. Sci. Technol. 2017, 51, 8405-8413. [CrossRef]

11. Dobermann, A.R. Nitrogen use efficiency-state of the art. Agron. Fac. Publ. 2005, 316. Available online: https://digitalcommons. unl.edu/agronomyfacpub/316 (accessed on 25 August 2021).

12. Barut, H. Effects of foliar urea, potassium and zinc sulphate treatments before and after flowering on grain yield, technological quality and nutrient concentrations of wheat. Appl. Ecol. Environ. Res. 2019, 17, 4325-4342. [CrossRef]

13. Rosecrance, R.; Johnson, R.; Weinbaum, S. The effect of timing of post-harvest foliar urea sprays on nitrogen absorption and partitioning in peach and nectarine trees. J. Hortic. Sci. Biotechnol. 1998, 73, 856-861. [CrossRef]

14. Khan, P.; Memon, M.Y.; Imtiaz, M.; Aslam, M. Response of wheat to foliar and soil application of urea at different growth stages. Pak. J. Bot. 2009, 41, 1197-1204.

15. Wagan, Z.A.; Buriro, M.; Wagan, T.A.; Wagan, Z.A.; Jamro, S.A.; Memon, Q.U.A.; Wagan, S.A. Effect of foliar applied urea on growth and yield of wheat (Triticum aestivium L.). Int. J. Bioorg. Chem. 2017, 2, 185-191.

16. Pospišil, A.; Varga, B.; Svečnjak, Z.; Carović, K. Influence of cropping system intensity on dry matter yield and nitrogen concentration in different parts of soybean plant. Agric. Conspec. Sci. 2006, 71, 51-57.

17. Saleem, I.; Javid, S.; Sial, R.A.; Ehsan, S.; Ahmad, Z.A. Substitution of soil application of urea with foliar application to minimize the wheat yield losses. Soil Environ. 2013, 32, 141-145.

18. Emam, Y.; Borjian, A. Yield and yield components of two winter wheat (Triticum aestivum L.) cultivars in response to rate and time of foliar urea application. J. Agric. Sci. Technol. 2000, 2, 263-270.

19. Görgüç, A.; Gençdă̆, E.; Yılmaz, F.M. Bioactive peptides derived from plant origin by-products: Biological activities and techno-functional utilizations in food developments-A review. Food Res. Int. 2020, 136, 109504. [CrossRef]

20. Osman, A.; Merwad, A.R.M.; Mohamed, A.H.; Sitohy, M. Foliar Spray with Pepsin-and Papain-Whey Protein Hydrolysates Promotes the Productivity of Pea Plants Cultivated in Clay Loam Soil. Molecules 2021, 26, 2805. [CrossRef]

21. Sitohy, M.Z.; Desoky, E.S.M.; Osman, A.; Rady, M.M. Pumpkin seed protein hydrolysate treatment alleviates salt stress effects on Phaseolus vulgaris by elevating antioxidant capacity and recovering ion homeostasis. Sci. Hortic. 2020, 271, 109495. [CrossRef]

22. Osman, A.; Imbabi, T.A.; El-Hadary, A.; Sabeq, I.I.; Edris, S.N.; Merwad, A.; Azab, E.; Gobouri, A.; Mohammadein, A.; Sitohy, M Health Aspects, Growth Performance, and Meat Quality of Rabbits Receiving Diets Supplemented with Lettuce Fertilized with Whey Protein Hydrolysate Substituting Nitrate. Biomolecules 2021, 11, 835. [CrossRef]

23. Colla, G.; Nardi, S.; Cardarelli, M.; Ertani, A.; Lucini, L.; Canaguier, R.; Rouphael, Y. Protein hydrolysates as biostimulants in horticulture. Sci. Hortic. 2015, 196, 28-38. [CrossRef]

24. Colla, G.; Rouphael, Y.; Canaguier, R.; Svecova, E.; Cardarelli, M. Biostimulant action of a plant-derived protein hydrolysate produced through enzymatic hydrolysis. Front. Plant Sci. 2014, 5, 448. [CrossRef]

25. Paul, K.; Sorrentino, M.; Lucini, L.; Rouphael, Y.; Cardarelli, M.; Bonini, P.; Reynaud, H.; Canaguier, R.; Trtílek, M.; Panzarová, K.; et al. Understanding the biostimulant action of vegetal-derived protein hydrolysates by high-throughput plant phenotyping and metabolomics: A case study on tomato. Front. Plant Sci. 2019, 10, 47. [CrossRef] [PubMed]

26. Osman, A.; Goda, H.A.; Abdel-Hamid, M.; Badran, S.M.; Otte, J. Antibacterial peptides generated by Alcalase hydrolysis of goat whey. LWT Food Sci. Technol. 2016, 65, 480-486. [CrossRef]

27. Sitohy, M.; Taha, S.; Osman, A.; Abdel-Hamid, M.; Hamed, A.; Abdelbacki, A. Antiviral action of native and methylated lactoferrin and $\beta$-Lactoglobulin against potato virus Y (PVY) infected into potato plants grown in an open field. Antibiotics 2020, 9, 430. [CrossRef] [PubMed] 
28. Sitohy, M.; Chobert, J.-M.; Haertlé, T. Esterified whey proteins can protect Lactococcus lactis against bacteriophage infection. Comparison with the effect of native basic proteins and L-polylysines. J. Agric. Food Chem. 2005, 53, 3727-3734. [CrossRef]

29. Sitohy, M.; Dalgalarrondo, M.; Nowoczin, M.; Besse, B.; Billaudel, S.; Haertlé, T.; Chobert, J.M. The effect of bovine whey proteins on the ability of poliovirus and Coxsackie virus to infect Vero cell cultures. Int. Dairy J. 2008, 18, 658-668. [CrossRef]

30. Sitohy, M.; Besse, B.; Billaudel, S.; Haertlé, T.; Chobert, J.M. Antiviral Action of Methylated $\beta$-Lactoglobulin on the Human Influenza Virus A Subtype H3N2. Probiotics Antimicrob. Proteins 2010, 2, 104-111. [CrossRef]

31. Abdelbacki, A.M.; Taha, S.H.; Sitohy, M.Z.; Abou Dawood, A.I.; Abd-El Hamid, M.M.; Rezk, A.A. Inhibition of tomato yellow leaf curl virus (TYLCV) using whey proteins. Virol. J. 2010, 7, 26. [CrossRef]

32. Taha, S.H.; Mehrez, M.A.; Sitohy, M.Z.; Abou Dawood, A.G.I.; Abd-El Hamid, M.M.; Kilany, W.H. Effectiveness of esterified whey proteins fractions against Egyptian Lethal Avian Influenza A (H5N1). Virol. J. 2010, 7, 330. [CrossRef]

33. Otte, J.; Abdel-Hamid, M.; Osman, A. Comparative assessment of peptide concentration in milk protein hydrolysates and fractions. Int. J. Dairy Sci. 2015, 10, 228-235. [CrossRef]

34. Abdel-Hamid, M.; Otte, J.; De Gobba, C.; Osman, A.; Hamad, E. Angiotensin I-converting enzyme inhibitory activity and antioxidant capacity of bioactive peptides derived from enzymatic hydrolysis of buffalo milk proteins. Int. Dairy J. 2017, 66, 91-98. [CrossRef]

35. Abdel-Hamid, M.; Goda, H.A.; De Gobba, C.; Jenssen, H.; Osman, A. Antibacterial activity of papain hydrolysed camel whey and its fractions. Int. Dairy J. 2016, 61, 91-98. [CrossRef]

36. El-Zahar, K.; Sitohy, M.; Choiset, Y.; Metro, F.; Haertle, T.; Chobert, J.M. Antimicrobial activity of ovine whey protein and their peptic hydrolysates. Milchwissenschaft 2004, 59, 653-656.

37. EL-Zahar, K.; Chobert, J.M.; Dalgalarrondo, M.; Sitohy, M.; Haertlé, T. Proteolysis of ewe's caseins and whey proteins during fermentation of yogurt and storage. Effect of the starters used. J. Food Biochem. 2004, 28, 319-335. [CrossRef]

38. Abdel-Hamid, M.; Osman, A.; El-Hadary, A.; Romeih, E.; Sitohy, M.; Li, L. Hepatoprotective action of papain-hydrolyzed buffalo milk protein on carbon tetrachloride oxidative stressed albino rats. J. Dairy Sci. 2020, 103, 1884-1893. [CrossRef]

39. Abdel-Hamid, M.; Romeih, E.; Saporito, P.; Osman, A.; Mateiu, R.V.; Mojsoska, B.; Jenssen, H. Camel milk whey hydrolysate inhibits growth and biofilm formation of Pseudomonas aeruginosa PAO1 and methicillin-resistant Staphylococcus aureus. Food Control 2020, 111, 107056. [CrossRef]

40. Adler-Nissen, J. Determination of the degree of hydrolysis of food protein hydrolysates by trinitrobenzenesulfonic acid. J. Agric. Food Chem. 1979, 27, 1256-1262. [CrossRef] [PubMed]

41. Ramadan, M.F.; Osman, A.; El-Akad, H. Total antioxidant potential of juices and beverages-Screening by DPPH in vitro assay. Wiss. Verl. Stuttg. 2008, 104, 235-239.

42. Osman, A.; El-Hadary, A.; Korish, A.A.; AlNafea, H.M.; Alhakbany, M.A.; Awad, A.A.; Abdel-Hamid, M. Angiotensin-I converting enzyme inhibition and antioxidant activity of papain-hydrolyzed camel whey protein and its hepato-renal protective effects in thioacetamide-induced toxicity. Foods 2021, 10, 468. [CrossRef]

43. Al-Mohammadi, A.-R.; Osman, A.; Enan, G.; Abdel-Shafi, S.; El-Nemer, M.; Sitohy, M.; Taha, M.A. Powerful antibacterial peptides from egg albumin hydrolysates. Antibiotics 2020, 9, 901. [CrossRef]

44. Zadoks, J.C.; Chang, T.T.; Konzak, C.F. A decimal code for the growth stages of cereals. Weed Res. 1974, 14, 415-421. [CrossRef]

45. Voldeng, H.; Simpson, G. The relationship between photosynthetic area and grain yield per plant in wheat. Can. J. Plant Sci. 1967, 47, 359-365. [CrossRef]

46. FAO. World Fertilizer Trends and Outlook to 2022; FAO: Rome, Italy, 2019.

47. Daba, N.A. Influence of nitrogen fertilizer application on grain yield, nitrogen uptake efficiency and nitrogen use efficiency of bread wheat (Triticum aestivum L.) cultivars in Eastern Ethiopia. J. Agric. Sci. 2017, 9, 202-217. [CrossRef]

48. Wang, D.; Xu, Z.; Zhao, J.; Wang, Y.; Yu, Z. Excessive nitrogen application decreases grain yield and increases nitrogen loss in a wheat-Soil system. Acta Agric. Scand. Sect. B Soil Plant Sci. 2011, 61, 681-692. [CrossRef]

49. Kong, L.; Xie, Y.; Hu, L.; Si, J.; Wang, Z. Excessive nitrogen application dampens antioxidant capacity and grain filling in wheat as revealed by metabolic and physiological analyses. Sci. Rep. 2017, 7, 43363. [CrossRef] [PubMed]

50. Yassen, A.; Abou El-Nour, E.; Shedeed, S. Response of wheat to foliar spray with urea and micronutrients. J. Am. Sci. 2010, 6, 14-22.

51. Schiavon, M.; Ertani, A.; Nardi, S. Effects of an alfalfa protein hydrolysate on the gene expression and activity of enzymes of the tricarboxylic acid (TCA) cycle and nitrogen metabolism in Zea mays L. J. Agric. Food Chem. 2008, 56, 11800-11808. [CrossRef]

52. Sestili, F.; Rouphael, Y.; Cardarelli, M.; Pucci, A.; Bonini, P.; Canaguier, R.; Colla, G. Protein hydrolysate stimulates growth in tomato coupled with N-dependent gene expression involved in N assimilation. Front. Plant Sci. 2018, 9, 1233. [CrossRef]

53. Youldash, K.M.; Barutcular, C.; El Sabagh, A.; Toptas, I.; Kayaalp, G.T.; Hossain, A.; Alharby, H.; Bamagoos, A.; Saneoka, H.; Farooq, M. Evaluation of grain yield in fifty-eight spring bread wheat genotypes grown under heat stress. Pak. J. Bot. 2020, 52, 33-42. [CrossRef]

54. Gurav, R.G.; Jadhav, J.P. A novel source of biofertilizer from feather biomass for banana cultivation. Environ. Sci. Pollut. Res. 2013, 20, 4532-4539. [CrossRef]

55. Miliauskas, G.; Venskutonis, P.; Van Beek, T. Screening of radical scavenging activity of some medicinal and aromatic plant extracts. Food Chem. 2004, 85, 231-237. [CrossRef] 
56. Foh, M.B.K.; Amadou, I.; Foh, B.M.; Kamara, M.T.; Xia, W. Functionality and antioxidant properties of tilapia (Oreochromis niloticus) as influenced by the degree of hydrolysis. Int. J. Mol. Sci. 2010, 11, 1851-1869. [CrossRef]

57. You, L.; Zhao, M.; Cui, C.; Zhao, H.; Yang, B. Effect of degree of hydrolysis on the antioxidant activity of loach (Misgurnus anguillicaudatus) protein hydrolysates. Innov. Food Sci. Emerg. Technol. 2009, 10, 235-240. [CrossRef]

58. Moreno-Hernández, J.M.; Benítez-García, I.; Mazorra-Manzano, M.A.; Ramírez-Suárez, J.C.; Sánchez, E. Strategies for production, characterization and application of protein-based biostimulants in agriculture: A review. Chil. J. Agric. Res. 2020, 80, 274-289. [CrossRef]

59. Fageria, N. Nitrogen harvest index and its association with crop yields. J. Plant Nutr. 2014, 37, 795-810. [CrossRef]

60. Triboi, E.; Martre, P.; Girousse, C.; Ravel, C.; Triboi-Blondel, A.M. Unravelling environmental and genetic relationships between grain yield and nitrogen concentration for wheat. Eur. J. Agron. 2006, 25, 108-118. [CrossRef] 